\title{
Foraminifera from the Aalenian and the Bajocian GSSP (Middle Jurassic) of Murtinheira section (Cabo Mondego, West Portugal): Biostratigraphy and paleoenvironmental implications
}

\author{
María Luisa Canales ${ }^{a}, *$, Maria Helena Henriques ${ }^{\text {b }}$ \\ a Departamento y UEI de Paleontología, Facultad de Ciencias Geológicas, Universidad Complutense de Madrid, \\ e Instituto de Geología Económica (CSIC-UCM), c/ José Antonio Novais, 2, 28040 Madrid, Spain \\ ${ }^{\mathrm{b}}$ Departamento de Ciências da Terra. Faculdade de Ciências e Tecnologia, Universidade de Coimbra, 3000-272 Coimbra, Portugal
}

Received 11 December 2006; received in revised form 18 December 2007; accepted 9 January 2008

\begin{abstract}
The detailed study of benthic foraminifera in 28 samples from Late Toarcian-Aalenian-Early Bajocian hemipelagic sediments of the Murtinheira section (Cabo Mondego, Lusitanian Basin, West Portugal), has permitted the recognition of the assemblage composition and the analysis of their evolution throughout this time interval. The representatives of the Suborder Lagenina dominate all the assemblages and, in the majority of them, the most abundant species is Lenticulina münsteri. The Late Toarcian and Early Aalenian assemblages are very similar. From the Comptum Subzone, a gradual replacement of the Early Jurassic forms by characteristic Middle Jurassic taxa takes place. During the Late Aalenian-Early Bajocian interval, a significant number of last occurrences (LOs) of taxa are recorded. The assemblages composition, the estimation of the relative taxa abundances and the data obtained from the calculation of several diversity indexes, together with the previous sedimentological and paleontological works in this area, indicate that these assemblages were developed in a shelfal basin environment. This platform showed normal marine salinity values, good oxygenation and was always located above calcite compensation depth (CCD). However, the environmental conditions were not always the best for the development of rich and diverse foraminiferal assemblages. These conditions were probably unstable during the Late Toarcian (Aalensis Subzone)-Early Aalenian (lower part of the Comptum Subzone). From the Comptum Subzone to the lower part of the Limitatum Subzone (Late Aalenian), conditions were more stable and more favourable for the development of foraminiferal communities. However, in the Aalenian-Bajocian transition the environmental conditions changed again and affected the development of this group. In the Limitatum Subzone a decrease in the diversity of the assemblages was recorded. This fact seems to be related to a global perturbation in the carbon-cycle that could have affected the foraminifera, together with other marine and continental organism groups.
\end{abstract}

(C) 2008 Elsevier B.V. All rights reserved.

Keywords: Foraminifera; Aalenian; Early-Middle Jurassic boundary; West Portugal; Biostratigraphy; Paleoecology

\footnotetext{
* Corresponding author. Tel.: +34 915445459 ; fax: +34 913944849.

E-mail addresses: mcanales@geo.ucm.es (M.L. Canales), hhenriq@dct.uc.pt (M.H. Henriques).
}

\section{Introduction}

The Murtinheira (also known as Cabo Mondego) section, located in the Cabo Mondego, Lusitanian Basin, western Portugal (Fig. 1A), is an outstanding outcrop where the Bajocian Global Stratotype Section and Point 


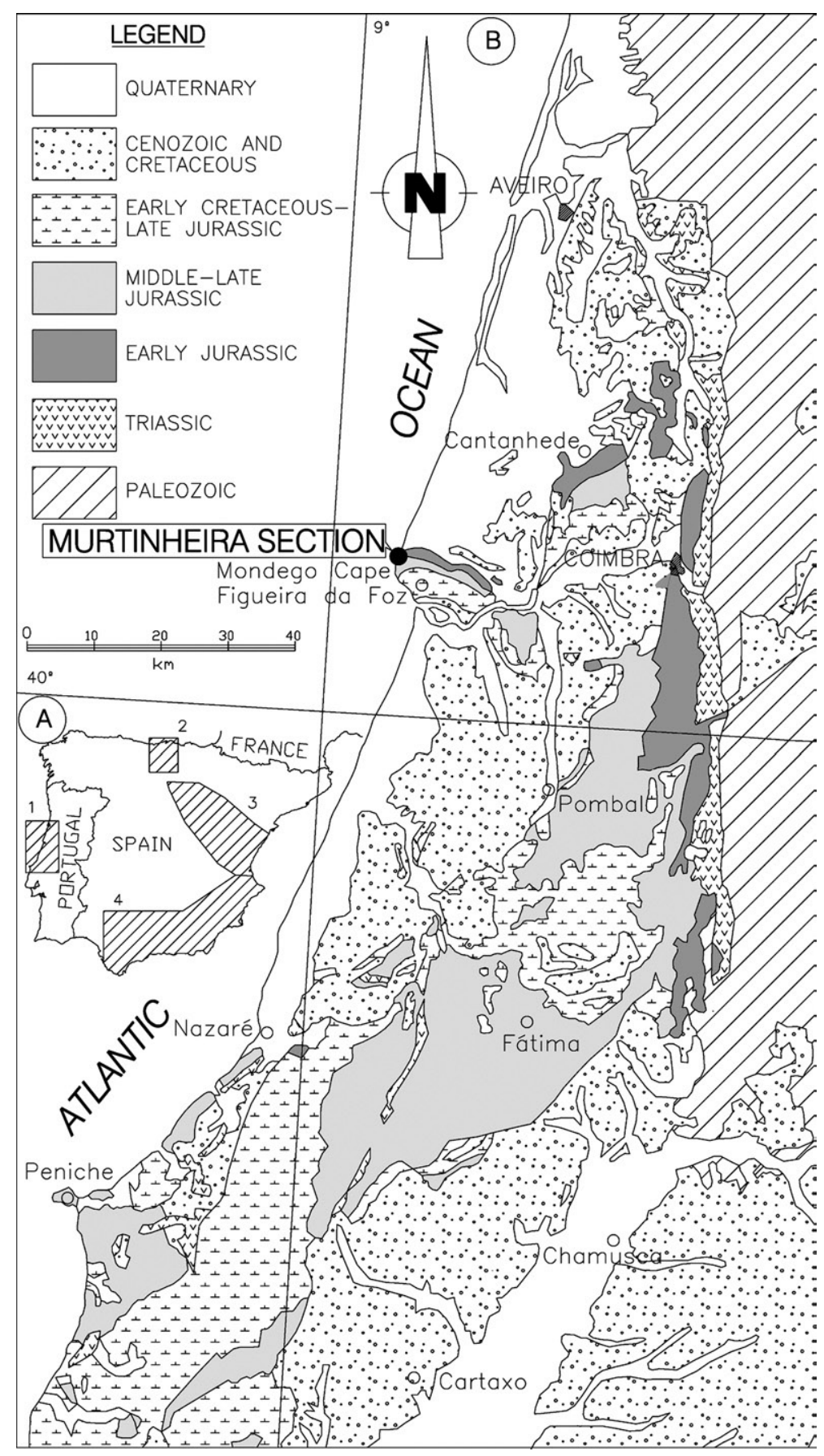

Fig. 1. (A) Location of the Lusitanian Basin (1), Basque-Cantabrian Basin (2), Iberian Range (3) and Betic Cordillera (4) in the Iberian Peninsula (B) Simplified geological map of the Lusitanian Basin (Western Portugal) showing the location of the Murtinheira section.

(GSSP), the first stratotype defined in the Jurassic System, was established in 1996 by the International Union of Geological Sciences. Its ratification was based on the record of ammonites and calcareous nannofossils assemblages and on magnetostratigraphy (Henriques et al.,
1994; Pavia and Enay, 1997). However, no detailed studies on the Upper Toarcian, Aalenian and Lowermost Bajocian foraminifera were performed until now.

As a reference section for Global Correlation, the Murtinheira section integrates the recently established 
Portuguese framework with international relevance "Jurassic record in the Lusitanian Basin" (Brilha et al., 2005; Henriques and Ramalho, 2005). Its classification as a Natural Monument, according to Portuguese legislation on Geoheritage, was ratified in October 2007.

Previous studies of the Early-Middle Jurassic transition in Portugal, based on foraminifera, are scarce (Exton, 1979; Exton and Gradstein, 1984; Ruget, 1985; Stam, 1985; Azerêdo, 1993, 1995, 1999; Henriques et al., 1995; Carapito and Henriques, 1999; Canales et al., 2000). The aims of this paper are: to study from a taxonomical, biostratigraphical and paleoecological point of view, the Late Toarcian-Aalenian-Early Bajocian foraminifera in the Murtinheira section, to contribute to the characterization and evolution of the paleoenvironments on which these assemblages were recorded and to compare some of the obtained results with other coeval sections of the Iberian Peninsula, located in the Basque-Cantabrian Basin and in the Iberian Range (Fig. 1A).

\section{Geographical location and geological setting}

The Murtinheira section is located in the western edge of the Iberian Peninsula, in the Lusitanian Basin, and is composed of a series of NE-SW trending outcrops of mainly Jurassic deposits (Fig. 1B) (Azerêdo et al., 2003). The general depositional framework is characterized by a marine alternation of marly and limestone sediments, in which the limestone component increases upwards. These were deposited from the Toarcian up to the Bathonian. This lithological variation also occurs laterally. The alternance of marls and limestones took place in the eastern part of the basin during latest Toarcian-earliest Aalenian and the lithological change was quite sudden. However, in the western part (Cabo Mondego), the change from the limestone deposition to the marls and limestones alternations is more progressive and did not occur until Middle Aalenian (Henriques, 1989). This differentiation is probably due to the activity of a major fracture axis (Arunca-Montemor) recognized in the region (Henriques, 1992, 1995).

The depositional environment in the Cabo Mondego area corresponds to a distal ramp established throughout the Toarcian (Duarte, 1997; Azerêdo et al., 2003). The absence of the Haugi and Murchisonae Subzones is a consequence of a regional discontinuity, recognizable at the base of the Middle Aalenian. This sedimentary break coincides with the base of the ZA 1 cycle of Haq et al. (1988).

\section{Description of the Murtinheira section}

The Murtinheira section displays a nearly continuous succession for the whole Middle Jurassic (Azerêdo et al., 2003). The access to the section is easy, showing a good exposition along cliffs, which are continually renewed by marine erosion. It is constituted by an alternation of limestones and marls in a more than $400 \mathrm{~m}$ thick succession of marine sediments, ranging from the Upper Toarcian to Middle Callovian (Rocha et al., 1990).

The deposits of the studied stratigraphic interval (Late Toarcian, Aalensis Subzone of the Aalensis Biozone to the Early Bajocian, Discites Biozone) correspond to the Cabo Mondego Formation (Azerêdo et al., 2003), whose thickness at Murtinheira is about $85 \mathrm{~m}$. The biostratigraphical units for this interval, established by Henriques (1992) based on the ammonite faunas, and the studied succession are shown in Fig. 2.

The Upper Toarcian sediments $(8.2 \mathrm{~m}$ thick) are composed of an alternation of marly limestone and marls. The Mactra Subzone is $2.2 \mathrm{~m}$ thick and the Aalensis Subzone, where ammonites, brachiopods, ichnofossils and iron oxide nodules are frequent, is $6 \mathrm{~m}$ thick.

In the Lower Aalenian, the Opalinum Subzone is quite condensed (1.1 m thick), in respect to other successions within the Lusitanian Basin. In level M-31, resedimented ammonite internal moulds are abundant.

The sediments corresponding to the Comptum Subzone ( $30 \mathrm{~m}$ thick) can be differentiated in two parts, providing distinct features. The lower one (level M-33 to level M-71; $11 \mathrm{~m}$ thick) is made up of very compact marly limestones and marls, organized in thickening upwards sequences that contain abundant ammonites, belemnites, plant remains, ichnofossils and iron oxide nodules. These levels alternate with thinning upwards marly sequences. The upper part (levels M-72 to $\mathrm{M}-121 ; 19 \mathrm{~m}$ thick) shows a monotonous rhythmic facies without significant gaps. It is constituted by marly limestones with abundant pyritous ichnofossils, ammonite nuclei and is locally rich in brachiopods. They alternate with marly levels containing pyritous ichnofossils and less frequent brachiopods and ammonites. Zoophycos are very abundant in level M-98. This upper part is bounded by sedimentary discontinuities where the discontinuity, identified between levels M121 and M-122 (Fig. 2), corresponds to a stratigraphic gap (lack of the Haugi and Bradfordensis Subzones) and displays a regional range.

At the Bradfordensis Biozone (35 m thick), two subzones were identified: the Bradfordensis Subzone 


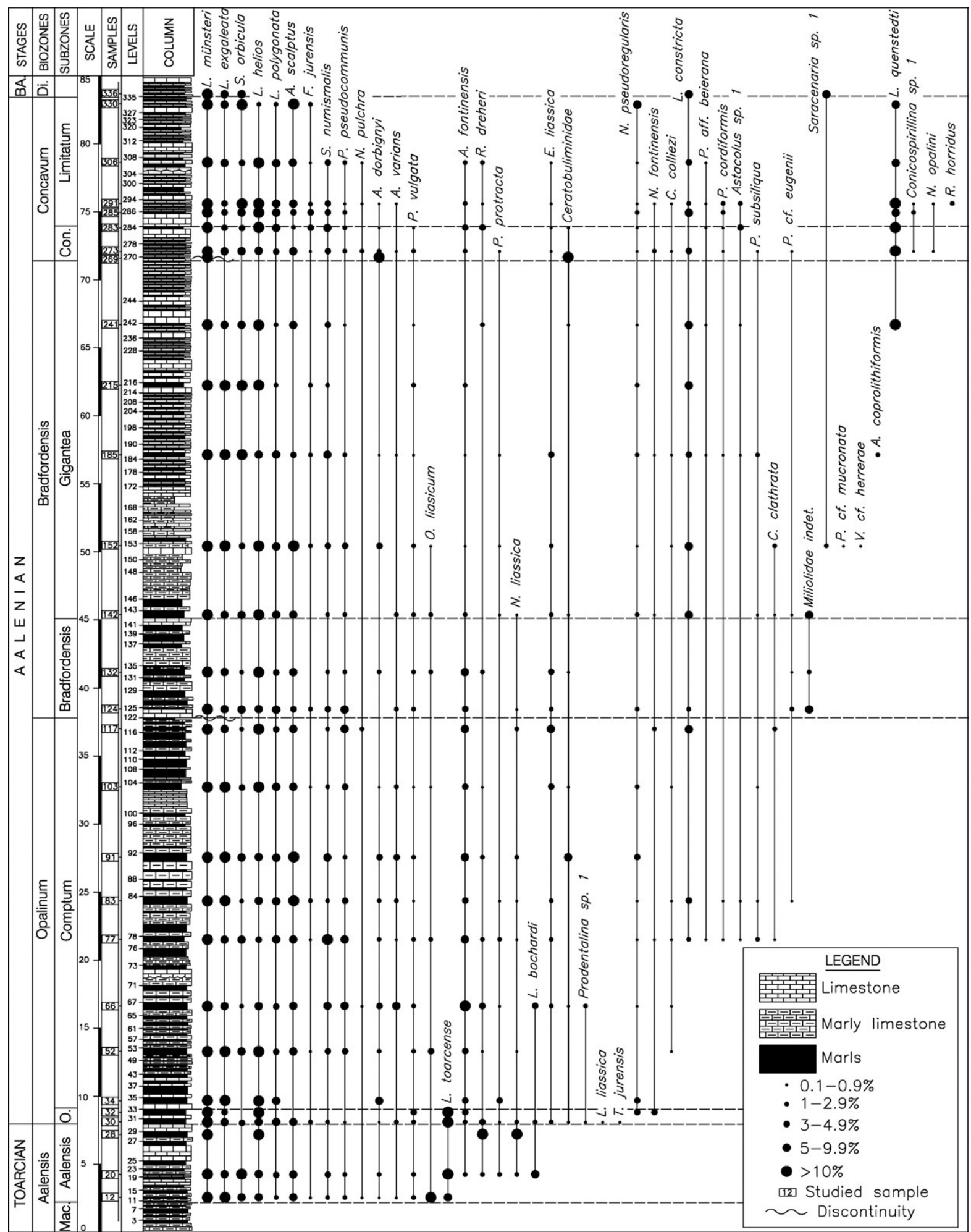

Fig. 2. Lithological succession, ammonite-based biostratigraphical units and the position of foraminiferal samples at Murtinheira section for the studied stratigraphic interval. Black dots show the occurrence and relative abundances of the taxa identified in each assemblage. Abbreviations: Mac.: Mactra Subzone; O.: Opalinum Subzone; Con.: Concavum Subzone; BA.: Bajocian; Di.: Discites Biozone. 
(8.5 m thick) and the Gigantea Subzone (26.5 m thick). At the Bradfordensis Subzone, two parts can be distinguished. The lower part (levels M-122 to M-129) is composed of reworked marly limestones and marls containing reelaborated ammonites. The upper part (level M-130 to level M-141) is made up of compact marly limestones that alternate with marls containing pyritous nodules and ichnofossils, ammonites, brachiopods and Zoophycos.

At the Gigantea Subzone four parts can be distinguished. Levels M-142 to M-155 are composed by thinning upwards sequences of compact marly limestones including pyritous nodules, Zoophycos, plant remains, ammonites, brachiopods and gastropods, that alternate with thin marly beds containing plant and ammonite remains. The second part (levels M-156 to M200 ) is constituted by very bioturbated marly limestones, where brachiopods are rather abundant. They alternate with thin marly beds containing abundant brachiopods and some belemnites. The third part (levels M-201 to M-216) is made up of very compact micritic limestones, locally rich in moulds of Lytoceratina drifted shells, with abundant pyritous ichnofossils and brachiopods. These alternate with marls, also rich in brachipods. The uppermost part (levels M-217 to M268 ) is made up of very compact micritic limestones, locally rich in moulds of Lytoceratina drifted shells, brachiopods and belemnites. These sediments alternate with marls, which sometimes are very bioturbated, and include small pyritous nodules and a great abundance of ichnofossils.

The Concavum Subzone (levels M-269 to M-283; $3 \mathrm{~m}$ thick) is constituted by compact micritic limestones organized in thinning upwards sequences, with abundant ammonites. They alternate with thin marly layers, locally abundant in brachiopodes.

The Limitatum Subzone (levels M-284 to level M$334 ; 9.3 \mathrm{~m}$ thick) is made up of very bioturbated micritic limestones, rich in ammonites, brachiopods and, less frequently, bivalves. Usually, the top of the carbonate levels is an irregular bored hardground and presents the highest concentration of ammonites. These levels alternate with highly bioturbated marly limestones bearing ammonites, brachiopods, belemnites and plant remains.

The first occurrence (FO) of an ammonite assemblage, containing different Toxolioceras species, has been recorded in level M-335 and it represents the lower boundary of the Discites Biozone (Bajocian GSSP). This biozone extends upwards until level M-341 (1 m thick) and the sediments are made up of compact micritic limestones alternating with bioturbated marls, bearing abundant ammonite remains randomly arranged and brachiopods.

The sediments representing the uppermost Toarcian and the Lower and Middle Aalenian have been interpreted as deposited in a hemipelagic environment, while the sediments corresponding to the Upper Aalenian (Limitatum Subzone) and to the Bajocian have been interpreted as lobe fringe facies association, related to fine-grained turbidites (Watkinson, 1989).

\section{Materials and methods}

To study the foraminifera content of the described succession, a total of 28 samples were collected, processed and analysed from several points of view. Sampling was based on previous biostratigraphic data, provided by the ammonoid record (Henriques, 1992, 1995). The sampling levels were selected taking into account the thickness of the ammonite subzones (Fig. 2) and the lithological features (marls or marly limestones). The samples were identified as M (Murtinheira) followed by the number of the level in the stratigraphic section.

Following the methodology proposed by Ruget et al. (1989), $300 \mathrm{~g}$ of each sediment sample was treated using an industrial surfactant liquid (Amine-O), combined with acetic acid and water. After boiling for $10 \mathrm{~min}$, hydrogen peroxide (30\%) was added. Subsequently, the samples were washed in a column of mesh sieves ( $1 \mathrm{~mm}, 0.5 \mathrm{~mm}, 0.250 \mathrm{~mm}, 0.125 \mathrm{~mm}$ and $0.060 \mathrm{~mm}$ ). Picking of the residues and the study of the foraminifera was carried out using a binocular magnifying glass (Wild M-8). The material, including residues and specimens, is stored at the Laboratório de Paleontologia, Departamento de Ciências da Terra, Faculdade de Ciências e Tecnologia, Universidade de Coimbra (Portugal). The photographs of the figured specimens were taken at the Centro de Microscopía Electrónica "Luis Brú", Universidad Complutense de Madrid, using an electronic microscope, model JEOL-JSM 6400.

With the purpose of obtaining paleoecological data, the species richness (number of specimens present in the sample), two diversity indexes (Fisher's $\alpha$ index and Margalef's richness index) and some indexes based on the proportional abundance of species (Simpson index, Berger-Parker index, Shannon-Wiener index and Equitability) were applied to determine the assemblages diversity. Calculation of these indexes was performed using PAST, a computer program conceived by Hammer et al. (2001), and Microsoft Excel.

To evaluate the diversity, one of the most widely-used indexes is the Fisher's $\alpha$ index, whose mathematical 


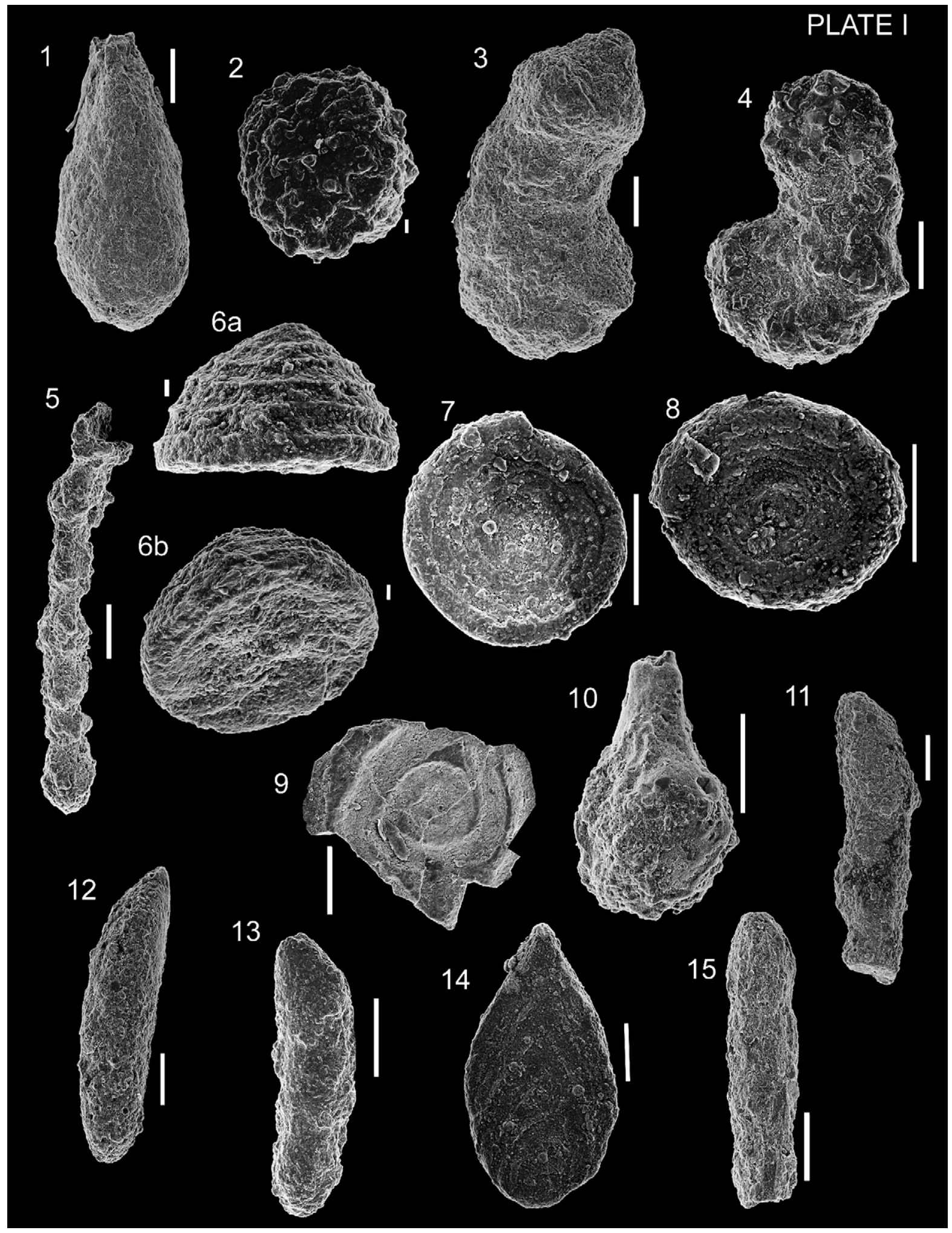


expression is $S=\alpha \ln (1+n / \alpha)$, where $S$ : number of species and $n$ : sample size (Hammer and Harper, 2006). Margalef's richness index relates the total number of species with the number of specimens in each sample. Its mathematical expression is $S=S-1 / \ln N$, where $S$ : number of species and $N$ : number of specimens (Magurran, 1988).

The Simpson index refers to the dominance of a species over the total number of species. It indicates the probability that two randomly picked individuals are of the same species and its mathematical expression is $\lambda=\Sigma p_{i}^{2}$, where $p_{i}=n_{i} / n$, being $n_{i}$ : number of specimens of each species and $n$ : total number of specimens (Hammer and Harper, 2006). If all the specimens of an assemblage correspond to a single species, then $\lambda=1$. The Berger-Parker's index quantifies the dominance by relating the number of specimens of the more abundant taxa with the samples' size (Hammer and Harper, 2006). The Shannon-Wiener index expresses the difficulty of predicting to which species will belong the next specimen obtained in an assemblage and its mathematical expression is $H^{\prime}=-\Sigma p_{i} \ln p_{i}$, where $p_{i}=n_{i} / n$, being $n_{i}$ : number of specimens of each species and $n$ : total number of specimens (Hammer and Harper, 2006). The lowest value of this index $\left(H^{\prime}=0\right)$ corresponds to a single taxa in the assemblage, while the highest values indicate a diverse assemblage. Equitability refers to the distribution of specimens among the species of an assemblage and its mathematical expression is $J=H^{\prime} / \ln S$, where $H^{\prime}$ : Shannon-Wiener index and $S$ : total number of species (Hammer and Harper, 2006). When all the species have the same number of specimens, then $J=1$, and this means that there is no dominance of any species.

\section{Results}

\subsection{Description of the assemblages}

From the 28 studied samples, a total of 5411 specimens have been obtained, corresponding to 5 suborders, 12 families, 19 genera and 42 species (Appendix A), most of which are represented in Plates I, II and III. Determination at the specific level was possible in most cases, mainly due to the good preservation of the specimens. Only in a few cases, determinations were limited to the generic level, or even to the family level, due to fragmentation, significant recrystallizations or dissolutions of the shells. This is the case of some of the specimens included in the Family Miliolidae and of the Ceratobuliminidae iron oxide internal moulds.

The composition of the foraminiferal assemblages recorded throughout the studied stratigraphic interval and the relative abundance of the identified taxa can be observed in Fig. 2. The percentages of the identified suborders in the assemblages are presented in Table 1.

\subsubsection{Late Toarcian, Aalensis Biozone, Aalensis Subzone}

From this subzone, 3 samples were studied. A small number of specimens were recovered $(129,104$ and 8 , respectively), corresponding to 20 species (Supplementary material; Table 1). The majority of the specimens obtained in these samples correspond to the Suborder Lagenina. The other suborders show irregular percentages (Table 1). Species of Spirillinina were obtained in M-12 and M-20, while specimens of Textulariina (only 1 in M-20) and Robertinina (1 in M-20 and 2 in M-28) are very scarce. The highest percentage of Miliolina was recognized in M-12 (30 specimens of Ophthalmidium liasicum). The most abundant genus and species are Lenticulina and Lenticulina münsteri.

Many identified species in these assemblages show a wide stratigraphic distribution and were found in most of the studied samples. Exceptions are Lenticulina toarcense and Lenticulina bochardi.

\subsubsection{Aalenian, Opalinum Biozone, Opalinum Subzone}

Due to the small thickness of this subzone, only 2 samples were studied, where 314 specimens were obtained and 25 taxa were identified (Supplementary

Plate I. (Scale bar $100 \mu$ ). 1. Lagenammina liassica (Barnard). M-30.1348. Aalenian, Opalinum Biozone, Opalinum Subzone. 2. Thurammina jurensis (Franke). (Scale bar $10 \mu$ ). M-30.1300. Aalenian, Opalinum Biozone, Opalinum Subzone. 3. Ammobaculites coprolithiformis (Schwager). M-185.1303. Aalenian, Bradfordensis Biozone, Gigantea Subzone. 4. Ammobaculites fontinensis (Terquem). M-91.1304. Aalenian, Opalinum Biozone, Comptum Subzone. 5. Reophax horridus (Schwager). M-291.1301. Aalenian, Concavum Biozone, Limitatum Subzone. 6a-6b. Conicospirillina sp 1. (Scale bar $10 \mu$ ). 6a: lateral view. 6b: apertural side. M-273.1346. Aalenian, Concavum Biozone, Concavum Subzone. 7. Spirillina numismalis Terquem and Berthelin. M-30.1353. Aalenian, Opalinum Biozone, Opalinum Subzone. 8. Spirillina orbicula Terquem and Berthelin. M-291.1352. Aalenian, Concavum Biozone, Limitatum Subzone. 9. Ophthalmidium liasicum (Kübler and Zwingli). Broken and microspheric specimen. M-12.1306. Toarcian, Aalensis Biozone, Aalensis Subzone. 10. Miliolidae spp. Broken specimen. M-124.1307. Aalenian, Bradfordensis Biozone, Bradfordensis Subzone. 11. Prodentalina pseudocommunis (Franke). M-103.1360. Aalenian, Opalinum Biozone, Comptum Subzone. 12. Prodentalina subsiliqua (Franke). M-103.1361. Aalenian, Opalinum Biozone, Comptum Subzone. 13. Prodentalina sp 1. M-66.1314. Aalenian, Opalinum Biozone, Comptum Subzone. 14. Falsopalmula jurensis (Franke). M-185.1363. Aalenian, Bradfordensis Biozone, Gigantea Subzone. 15. Nodosaria fontinensis Terquem. Broken specimen. M-273.1347. Aalenian, Concavum Biozone, Concavum Subzone. 


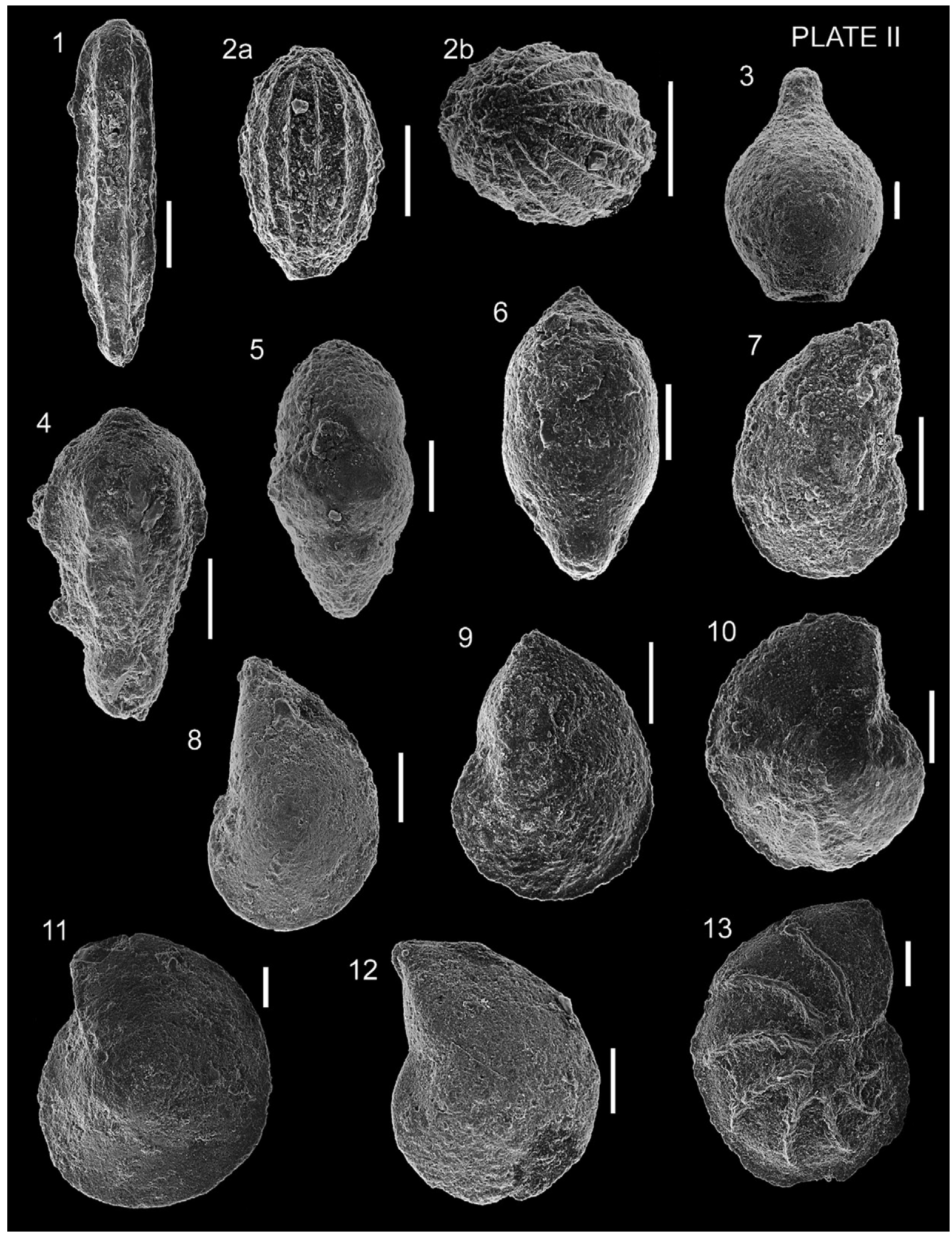


material; Table 2). In these assemblages, again Lagenina is the best-represented suborder. Regarding the remaining suborders, in M-30 specimens of Spirillinina, Robertinina and Textulariina were identified, while in M-32 only representatives of Textulariina were recovered (Table 1). In both cases, Lenticulina is the dominant genus. In M-30, Lenticulina toarcense is the most abundant species, with 67 specimens $(23.4 \%$ of the total), while in M-32 the species with most specimens is Lenticulina münsteri.

Concerning their stratigraphic range, out of the 23 identified taxa in M-30, 18 were already present in the Late Toarcian assemblages. The FOs of Eoguttulina liassica, specimens of the Family Ceratobuliminidae, Prodentalina sp. 1, Lagenammina liassica and Thurammina jurensis are recorded. In spite of the small number of recovered specimens and identified taxa, in M-32 the FO of 2 species (Nodosaria pseudoregularis and Nodosaria fontinensis) occurs. Both show a wide distribution range at Murtinheira, especially Nodosaria pseudoregularis, which is present in most of the remaining assemblages. Also, in M-32 the LO of Lenticulina toarcense, a typical Early Jurassic species, is recorded.

\subsubsection{Aalenian, Opalinum Biozone, Comptum Subzone}

From this subzone, 8 samples were studied. A total of 1641 specimens were recovered and 32 taxa were identified (Supplementary material; Table 3). In M-34 only 30 specimens were recovered, with a clear prevalence of the Suborder Lagenina over Textulariina (Table 1). All the identified species have already been recorded in the preceding assemblages. The most abundant species is Lenticulina münsteri, which exceeds $56 \%$.

The number of specimens increases considerably in the following 4 assemblages (Fig. 3A). Once again, the most abundant suborder is Lagenina (92\%). Only in M52 and M-77, the 5 identified suborders were recognized. In M-66, the specimens of Textulariina, all of them corresponding to Ammobaculites fontinensis, attain the highest percentage (Table 1). Lenticulina münsteri is the most abundant species, with the exception of M-77, where 71 specimens of Spirillina numismalis were identified, against 48 of Lenticulina münsteri.

Regarding the distribution ranges of the identified taxa, many of them were already present in the preceding assemblages. However, several FOs and LOs occur throughout this interval. In M-52, the FO of Citharina colliezi, and in M-66 the LO of Prodentalina sp. 1 and Lenticulina bochardi - a typical Early Jurassic species - are recorded. In M-77, the FO of Lenticulina constricta, a relatively important species in the succeeding assemblages, Planularia aff. beierana, Planularia cordiformis, Astacolus sp. 1, Prodentalina subsiliqua and Citharina clathrata, also occurs. Except for the last-mentioned species, whose distribution range is more restricted, the species identified for the first time in this assemblage show a wide distribution range at Murtinheira. The FO of Planularia cf. eugenii occurs in M-83, which presents an occasional and discontinuous record in this section.

In the 3 remaining samples, a variable number of specimens were recovered (Fig. 3A). The Suborder Lagenina continues to prevail, followed by Spirillinina and Textulariina, while Miliolina and Robertinina, when present, may be considered as a minority (Table 1). Hence, only in M-103 specimens of the 5 identified suborders were recognized. The largest number of specimens corresponds to different species of the genus Lenticulina.

\subsubsection{Aalenian, Bradfordensis Biozone, Bradfordensis Subzone}

From the Bradfordensis Subzone, 2 samples were studied. A total of 345 specimens were recovered and 22 taxa were identified (Supplementary material; Table 4). The Suborder Lagenina continues to be the most abundant in both assemblages (Table 1). The remaining suborders were identified, with the exception of Robertinina, absent in M-124. Again, the best-represented genus is Lenticulina, and Lenticulina münsteri is the most abundant species. The taxonomic composition of these assemblages is very similar to that of the

\footnotetext{
Plate II. (Scale bar $100 \mu$ ). 1. Nodosaria liassica Barnard. M-30.1315. Aalenian, Opalinum Biozone, Opalinum Subzone. 2a-2b. Nodosaria opalini Bartenstein. Broken specimen, with a single chamber. 2a: lateral view. 2b: subapertural view. M-291.1351. Aalenian, Concavum Biozone, Limitatum Subzone. 3. Nodosaria pseudoregularis Canales. Broken specimen, with a single chamber. M-103.1364. Aalenian, Opalinum Biozone, Comptum Subzone. 4. Nodosaria pulchra (Franke). M-291.1317. Aalenian, Concavum Biozone, Limitatum Subzone. 5. Pseudonodosaria vulgata (Bornemann). M-83.1354. Aalenian, Opalinum Biozone, Comptum Subzone. 6. Pseudonodosaria vulgata (Bornemann). M-142.1318. Aalenian, Bradfordensis Biozone, Gigantea Subzone. 7. Lenticulina bochardi (Terquem). M-20.1355. Toarcian, Aalensis Biozone, Aalensis Subzone. 8. Lenticulina constricta (Kaptarenko-Chernousova) sensu Jendryka-Fuglewicz. M-152.1356. Aalenian, Bradfordensis Biozone, Gigantea Subzone. 9. Lenticulina exgaleata Dieni. M-12.1321. Toarcian. Aalensis Biozone, Aalensis Subzone. 10. Lenticulina helios (Terquem). M-152.1322. Aalenian, Bradfordensis Biozone, Gigantea Subzone. 11. Lenticulina münsteri (Roemer). M-273.1326. Aalenian, Concavum Biozone, Concavum Subzone. 12. Lenticulina polygonata (Franke). M-241.1357. Aalenian, Bradfordensis Biozone, Gigantea Subzone. 13. Lenticulina quenstedti (Gümbel). M-291.1327. Aalenian, Concavum Biozone, Limitatum Subzone.
} 


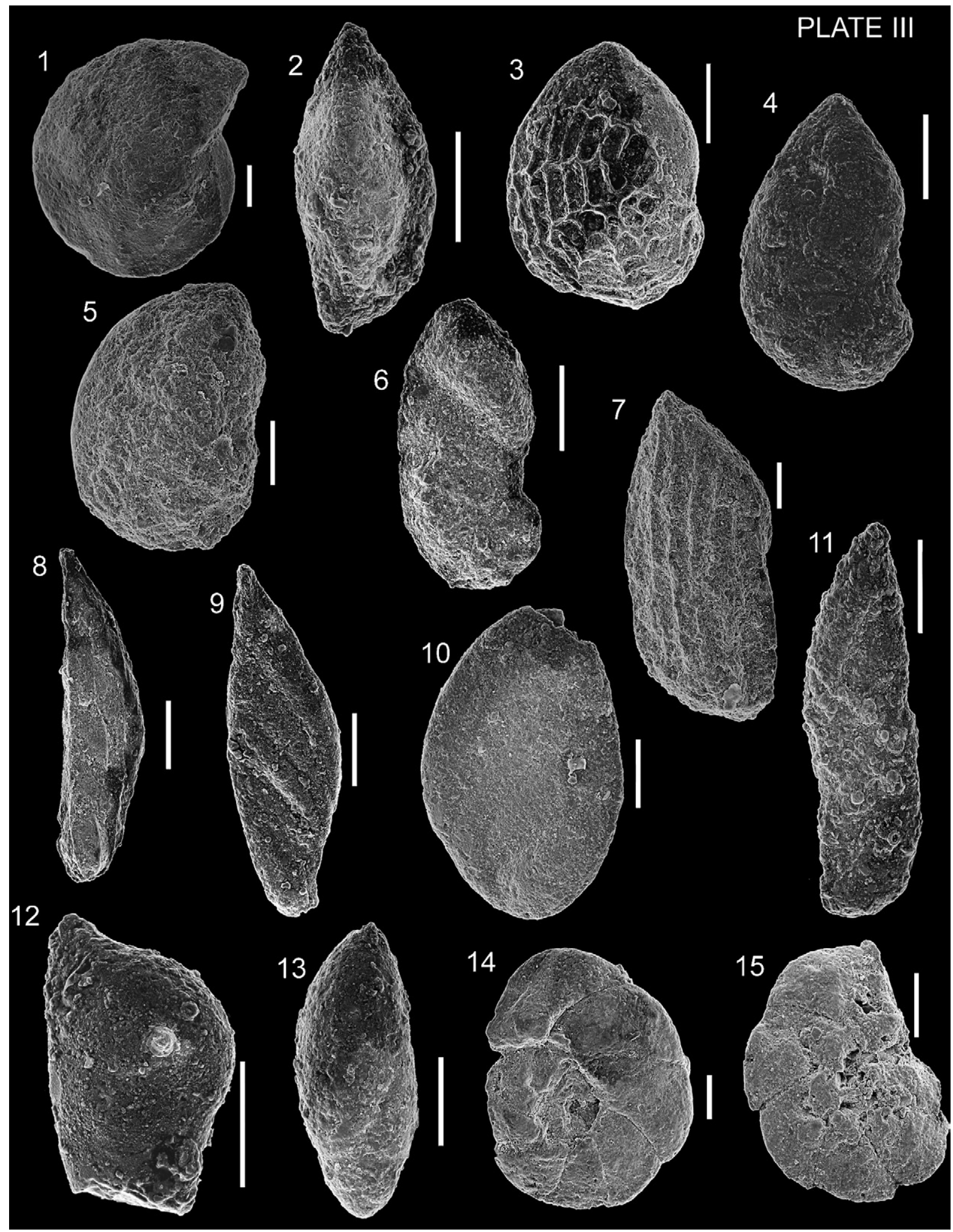


Table 1

Relative abundances (percentages) of the suborders identified for the studied samples

\begin{tabular}{llclll}
\hline & Textulariina & Spirilinina & Miliolina & Lagenina & Robertinina \\
\hline M-12 & 0 & 10.5 & 24.2 & 65.3 & 0 \\
M-20 & 1.1 & 17 & 0 & 80.9 & 1.1 \\
M-28 & 0 & 0 & 0 & 71.4 & 28.6 \\
M-30 & 3.7 & 7 & 0 & 84.8 & 4.5 \\
M-32 & 3.7 & 0 & 0 & 96.3 & 0 \\
M-34 & 3.3 & 0 & 0 & 96.7 & 0 \\
M-52 & 4.2 & 10.2 & 5.1 & 79.7 & 0.8 \\
M-66 & 13.3 & 8.6 & 0 & 73.8 & 4.3 \\
M-77 & 5.6 & 25.9 & 1.2 & 66.1 & 1.2 \\
M-83 & 4.4 & 3.1 & 0 & 92.5 & 0 \\
M-91 & 5.3 & 16.1 & 0 & 67.9 & 10.7 \\
M-103 & 5.2 & 7.5 & 0.4 & 85 & 1.9 \\
M-117 & 6.1 & 6.1 & 0 & 87.8 & 0 \\
M-124 & 3.9 & 11 & 8.8 & 76.3 & 0 \\
M-132 & 6.3 & 6.3 & 3.1 & 81.9 & 2.4 \\
M-142 & 2.4 & 9.8 & 7.8 & 79.6 & 0.4 \\
M-152 & 0.7 & 8.1 & 0.3 & 90.9 & 0 \\
M-185 & 2.1 & 21.6 & 0 & 76.3 & 0 \\
M-215 & 3 & 18.2 & 0 & 78.8 & 0 \\
M-241 & 0 & 9.9 & 0 & 87 & 3.1 \\
M-269 & 0 & 0 & 0 & 66.7 & 33.3 \\
M-273 & 1 & 11.6 & 0 & 87.4 & 0 \\
M-283 & 4 & 11 & 0 & 80 & 5 \\
M-285 & 0 & 13 & 0 & 87 & 0 \\
M-291 & 4 & 14.8 & 0 & 80.3 & 0.9 \\
M-306 & 1.4 & 8.5 & 1.4 & 85.9 & 2.8 \\
M-330 & 0 & 27.3 & 0 & 72.7 & 0 \\
M-336 & 0 & 9.1 & 0 & 90.9 & 0 \\
\hline & & & & & \\
\hline
\end{tabular}

preceding ones, except for the Family Miliolidae whose FO occurs in M-124.

\subsubsection{Aalenian, Bradfordensis Biozone, Gigantea Subzone}

In the Gigantea Subzone, 5 samples were studied. A total of 1062 specimens were obtained and 35 taxa were identified (Supplementary material; Table 5). In the first 3 samples, a relatively high number of specimens were obtained (Fig. 3A). Only in M-142 all the suborders were identified. In M-185, Spirillinina attains a significant percentage, but all of these assemblages are mainly constituted by specimens of Lagenina (Table 1), specifically of the genus Lenticulina, being Lenticulina münsteri the most abundant species.

Regarding the stratigraphic range of the identified taxa, the LO of Nodosaria liassica and specimens of the Family Miliolidae occur in M-142. One of the most important features of the M-152 assemblage is the LO of Ophthalmidium liasicum and Citharina clathrata and the FO of Saracenaria sp. 1, Prodentalina cf. mucronata and Vaginulina cf. herrerae. These last two species were not identified in any other assemblage. Ammobaculites coprolithiformis, a typical Middle Jurassic species, was recognized only in M-185.

In the two assemblages corresponding to the upper part of the Gigantea Subzone, the number of specimens and taxa is smaller than in the preceding ones (Fig. 3A and B). From a taxonomic point of view, they are very similar to the previous ones, with a clear prevalence of Lagenina over the other suborders. In M-215, Spirillinina attains a high percentage, while Textulariina may be considered as a minority (Table 1). Lenticulina and Lenticulina münsteri are the most abundant genus and species, respectively. The obtained specimens correspond to previously identified taxa. An exception to this is Lenticulina quenstedti, whose FO is in M-241. This typical Middle Jurassic species plays an important role in the successive assemblages.

\subsubsection{Aalenian, Concavum Biozone, Concavum Subzone}

The Concavum Subzone is represented by 3 samples. A total of 740 specimens were recovered and 30 taxa were identified (Supplementary material; Table 6). The lowest number of specimens and taxa, corresponding to Lagenina and Robertinina, were found in M-269 (Fig. 3A and B). However, in spite of the high number of specimens (624) and taxa (26) recorded in M-273, only the Suborders Lagenina, Spirillinina and Textulariina were identified. In M-283, a number of specimens and taxa significantly lower than that of the preceding assemblage were recorded. In these assemblages, the prevalent suborder is Lagenina (Table 1). At the specific level, Lenticulina münsteri continues to be the most abundant species.

Plate III. (Scale bar $100 \mu$ ). 1. Lenticulina toarcense Payard, M-30.1358. Aalenian, Opalinum Biozone, Opalinum Subzone. 2. Saracenaria sp 1. M152.1344. Aalenian, Bradfordensis Biozone, Gigantea Subzone. 3. Astacolus dorbignyi (Roemer). M-273.1330. Aalenian, Concavum Biozone, Concavum Subzone. 4. Astacolus scalptus (Franke). M-273.1331. Aalenian, Concavum Biozone, Concavum Subzone. 5. Astacolus varians (Bornemann). M-124.1332. Aalenian, Bradfordensis Biozone, Bradfordensis Subzone. 6. Astacolus sp 1. M-283.1333. Aalenian, Concavum Biozone, Concavum Subzone. 7. Citharina clathrata (Terquem). Broken specimen. M-77.1335. Aalenian, Opalinum Biozone, Comptum Subzone. 8. Citharina colliezi (Terquem). M-291.1349. Aalenian, Concavum Biozone, Limitatum Subzone. 9. Planularia aff. beierana (Gümbel). M291.1339. Aalenian, Concavum Biozone, Limitatum Subzone. 10. Planularia cordiformis (Terquem). M-291.1337. Aalenian, Concavum Biozone, Limitatum Subzone. 11. Planularia protracta (Bornemann). M-77.1338. Aalenian, Opalinum Biozone, Comptum Subzone. 12. Vaginulina cf. herrerae Canales. Broken specimen. M-152.1350. Aalenian, Bradfordensis Biozone, Gigantea Subzone. 13. Eoguttulina liassica (Strickland). M-77.1345. Aalenian, Opalinum Biozone, Comptum Subzone. 14. Ceratobuliminidae. Dorsal view. M-91.1340. Aalenian, Opalinum Biozone, Comptum Subzone. 15. Ceratobuliminidae. Ventral view. M-142.1341. Aalenian, Bradfordensis Biozone, Gigantea Subzone. 


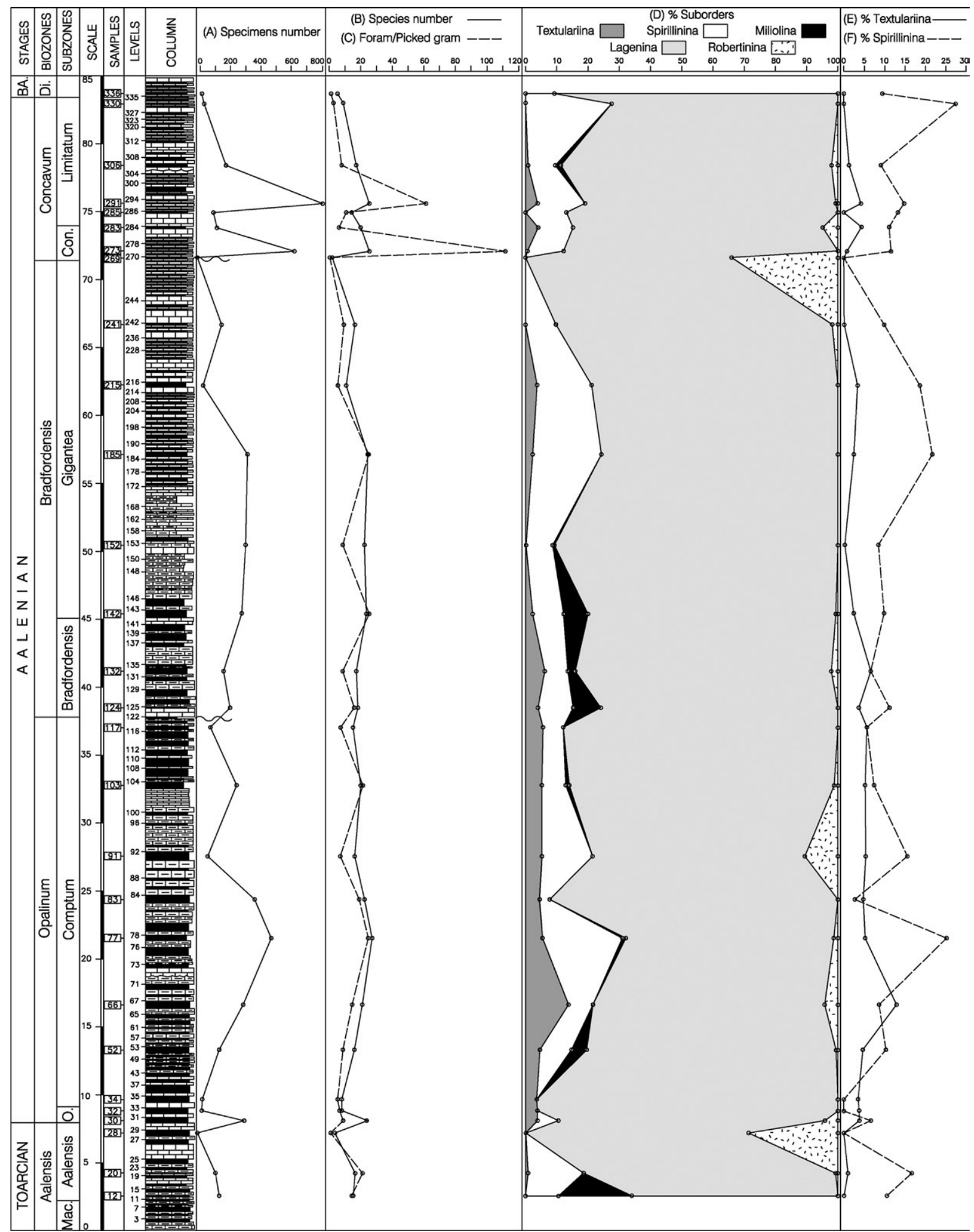


The assemblages from M-269 and M-273 are composed of previously identified taxa. In M-273 the LO of Planularia protracta, Prodentalina subsiliqua and Planularia cf. eugenii were recognized. In the same level, the FO of Conicospirillina sp. 1 and Nodosaria opalini, were also recognized, both of which display a very short distribution. In M-283, the assemblage is composed of previously identified taxa, being the LO of Pseudonodosaria vulgata and of the Family Ceratobuliminidae the most relevant feature.

\subsubsection{Aalenian, Concavum Biozone, Limitatum Subzone}

In the Limitatum Subzone, 4 samples were studied. A total of 1060 specimens were obtained and 26 species were identified (Supplementary material; Table 7). In M285, M-306 and M-330, a relatively low number of specimens were recovered, while in M-291 the highest number of specimens was obtained (Fig. 3A). In M-285 and M-330 only representatives of Lagenina and Spirillinina were identified, while in M-291 and M-306 specimens of Textulariina and Robertinina were also recognized. In these assemblages, Lagenina prevails (Table 1), and the most abundant species continues to be Lenticulina münsteri. However, Spirillina orbicula reaches its maximum percentage in M-330.

All the identified species in M-285 and M-291 were present in the preceding assemblages. In M-291, the LOs of the following taxa were identified: Astacolus dorbignyi and Astacolus varians - present in this section since the Upper Toarcian deposits -, Nodosaria fontinensis, Citharina colliezi, Planularia cordiformis and Astacolus sp. 1 - whose distribution spreads throughout all or a great part of the Aalenian -, as well as Conicospirillina sp. 1 and Nodosaria opalini - whose range is limited to the Late Aalenian at Murtinheira. Reophax horridus was the only species whose FO was identified.

Important changes are recorded in the following assemblages. From this assemblage (M-291) upwards no other FOs were detected and the number of species in the overlying samples is progressively smaller. Accordingly, assemblage M-306 records the LOs of the following 7 species: Spirillina numismalis, Prodentalina pseudocommunis, Nodosaria pulchra, Ammobaculites fontinensis, Reinholdella dreheri, Eoguttulina liassica and Planularia aff. beierana. In addition, in M-330 the
LOs in the studied samples of 6 species - Lenticulina helios, Lenticulina polygonata, Astacolus scalptus, Falsopalmula jurensis, Nodosaria pseudoregularis and Lenticulina quenstedti -, are recorded, some of which are important constituents of the studied assemblages.

\subsubsection{Bajocian, Discites Biozone}

Only 1 sample was studied and 6 taxa were identified (Supplementary material; Table 8). In this assemblage only 15 specimens, corresponding to Lagenina and Spirillinina, were recognized (Table 1). It is worth noting that half of the Lagenina specimens correspond to Lenticulina münsteri. All the identified taxa were already present in preceding assemblages.

\subsection{Biostratigraphical remarks}

Based on the distribution range and on the relative abundance of foraminifera (Fig. 2), certain biostratigraphical considerations, valid for the Murtinheira section, can be pointed out. The studied assemblages presented above are composed of a variable number of specimens and taxa (Fig. 3A and B) that can be separated into five groups.

The first group includes species with a wide distribution range, a continuous record and a high abundance: Lenticulina münsteri, Lenticulina exgaleata, Spirillina orbicula, Lenticulina polygonata and Astacolus scalptus. They show significant percentages and their continuous record and high abundance make the assemblages look quite homogeneous. However, detailed taxonomic analysis throughout the studied stratigraphic interval contradicts this homogeneity.

The second group includes species with a wide distribution range, but these species show a more discontinuous record than the previous group. With some exceptions, such species do not present a significant abundance. They are Falsopalmula jurensis, Spirillina numismalis (with a high abundance in M-77), Prodentalina pseudocommunis, Astacolus dorbignyi, Astacolus varians, Ammobaculites fontinensis (with numerous specimens in M-66), Eoguttulina liassica, Nodosaria pseudoregularis and Lenticulina constricta. Although some of them are typical Early Jurassic species, some typical Middle Jurassic species, such as Ammobaculites

Fig. 3. (A) Distribution of the number of specimens obtained for the studied samples. Notice the irregular amount of specimens recorded throughout the considered stratigraphic interval. (B) Number of taxa identified in each assemblage and (C) relationship between the number of foraminifera obtained in each sample per gram of sediment picked. As observed, these two factors are not directly related. (D) Percentages of the suborders identified in the foraminiferal assemblages recognized at Murtinheira. The diagram shows the clear prevalence of Lagenina, followed by Spirillinina and Textulariina, as well as the scarcity of Miliolina and Robertinina. (E) Percentages of Textulariina and (F) percentages of Spirillinina obtained for the studied assemblages. No apparent direct relationship between the variations of the percentages of both suborders can be observed. 
fontinensis, Lenticulina constricta or Nodosaria pseudoregularis are also present in this group.

The third group is composed of taxa with a relatively wide distribution range. However, their record is much more sporadic and most of them represent minor percentages in the assemblages. These taxa are Nodosaria pulchra, Reinholdella dreheri, Planularia protracta, Nodosaria fontinensis and Citharina colliezi, as well as internal moulds of specimens included in the Family Ceratobuliminidae. Except for Planularia protracta, defined originally in the Lower Jurassic (Carixian) sediments from Germany, the remaining species that make up this group were defined in sediments belonging to the upper part of the Lower Jurassic and to the Middle Jurassic.

In the fourth group, only species identified in the lower and middle part of the studied stratigraphic interval are included. They are Ophthalmidium liasicum, Lenticulina toarcense, Nodosaria liassica, Lenticulina bochardi, Prodentalina sp. 1, Lagenammina liassica and Thurammina jurensis. All of them were originally described in Lower Jurassic deposits, although they were subsequently found in Middle Jurassic sediments. Ophthalmidium liasicum and Nodosaria liassica present a somewhat wider distribution range and their LOs are recorded in the Aalenian, Bradfordensis Biozone (Gigantea Subzone), at Murtinheira. Although their record is quite continuous, they usually present a low percentage. On the other hand, the typical Toarcian species Lenticulina toarcense and Lenticulina bochardi record their LOs in the Opalinum and Comptum Subzones, respectively. These display significant percentages in the assemblages. It is worth noting that, in this section, Lagenammina liassica and Thurammina jurensis show a distribution range restricted to the Opalinum Subzone. In the Basque-Cantabrian Basin, Lagenammina liassica ranges from the Late Toarcian to the Late Aalenian and Thurammina jurensis has been recorded from the Late Toarcian to the Middle Aalenian (Canales, 2001).

The fifth group includes identified taxa from the middle and upper part of the studied stratigraphic interval. Most of them show a discontinuous record and are only found in some of the studied assemblages, where they are usually minority constituents. The only exceptions are the specimens of the Family Miliolidae, whose range at Murtinheira is restricted to the lower part of the Middle Aalenian, and Lenticulina quenstedti, which shows a continuous record from the Gigantea Subzone to the top of the Aalenian. The other taxa of this group present variable distribution ranges (Fig. 2). Citharina clathrata, defined originally in the upper part of the Lower Jurassic sediments, shows in this section a distribution range that is limited to the Comptum Subzone-lower part of the Gigantea Subzone interval. At Murtinheira, the FO of Saracenaria sp. 1, Lenticulina quenstedti, Prodentalina cf. mucronata, Vaginulina cf. herrerae and Ammobaculites coprolithiformis is recorded in the Gigantea Subzone. The 3 last species show a record restricted to this subzone. Finally, in the Concavum Biozone, the FO of Nodosaria opalini, Conicospirillina sp. 1 and Reophax horridus occurs, showing a short distribution range and low abundance. The taxa, whose FO at Murtinheira is recorded in the Gigantea Subzone, are typical of the Middle Jurassic.

In summary, throughout the studied stratigraphic interval, the most abundant species were found in almost all of the assemblages, which gives us the appearance of a certain homogeneity. However, throughout this stratigraphic interval, a gradual disappearance of typical Early Jurassic species (i.e. Lenticulina toarcense, Lenticulina bochardi, Lagenammina liassica, Thurammina jurensis, Nodosaria liassica, Ophthalmidium liasicum, Citharina clathrata) and a progressive appearance of Middle Jurassic species (i.e. Lenticulina constricta, Nodosaria fontinensis, Planularia aff. beierana, Vaginulina cf. herrerae, Ammobaculites coprolithiformis, Lenticulina quenstedti, Nodosaria opalini) takes place.

It is important to remark that, in the assemblages of the Concavum Biozone, the LO of numerous taxa (27) is recorded. Disappearances of such an important amount of taxa could be related to the presence of a significant extinction interval in this time span. However, the last two studied assemblages are composed of a small number of specimens and taxa. This fact does not necessarily discard the possibility of an extinction event, and could even support it. To test this hypothesis it would be necessary to analyse the following Lower Bajocian assemblages and therefore verify if these LOs are effective or if they result from the Lazarus effect.

\subsection{Paleoecology}

In the studied samples, the high percentage of determinable specimens (98.9\%) is an index of their good state of preservation. Taphonomic processes changing the composition of the assemblages are considered as negligible. Only occasionally, shell fragmentation, surface recrystallization and dissolution of some of the most unstable shells, were observed. Such taphonomic changes may sometimes make identifications difficult.

The number of specimens obtained in each sample is quite variable (Fig. 3A), from a maximum of 780 to a 
Table 2

Relative abundances (percentages) of the genera identified in the studied assemblages

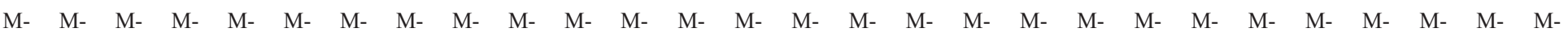
$\begin{array}{llllllllllllllllllllllllllllll}12 & 20 & 28 & 30 & 32 & 34 & 52 & 66 & 77 & 83 & 91 & 103 & 117 & 124 & 132 & 142 & 152 & 185 & 215 & 241 & 269 & 273 & 283 & 285 & 291 & 306 & 330 & 336\end{array}$

\begin{tabular}{|c|c|c|c|c|c|c|c|c|c|c|c|c|c|c|c|c|c|c|c|c|c|c|c|c|c|c|c|c|}
\hline Lagenammina & 0 & 0 & 0 & 0.4 & 0 & 0 & 0 & 0 & 0 & 0 & 0 & 0 & 0 & 0 & 0 & 0 & 0 & 0 & 0 & 0 & 0 & 0 & 0 & 0 & 0 & 0 & 0 & 0 \\
\hline Thurammina & 0 & 0 & 0 & 0.4 & 0 & 0 & 0 & 0 & 0 & 0 & 0 & 0 & 0 & 0 & 0 & 0 & 0 & 0 & 0 & 0 & 0 & 0 & 0 & 0 & 0 & 0 & 0 & 0 \\
\hline Reophax & 0 & 0 & 0 & 0 & 0 & 0 & 0 & 0 & 0 & 0 & 0 & 0 & 0 & 0 & 0 & 0 & 0 & 0 & 0 & 0 & 0 & 0 & 0 & 0 & 2.6 & 0 & 0 & 0 \\
\hline Ammobaculites & 0 & 1 & 0 & 2.8 & 3.6 & 3.3 & 4.1 & 12.2 & 5.1 & 3.9 & 5.1 & 4.7 & 5.3 & 3.6 & 5.4 & 2.2 & 0.7 & 1.9 & 2.8 & 0 & 0 & 1 & 3.5 & 0 & 1.3 & 1.2 & 0 & 0 \\
\hline Conicospirillina & 0 & 0 & 0 & 0 & 0 & 0 & 0 & 0 & 0 & 0 & 0 & 0 & 0 & 0 & 0 & 0 & 0 & 0 & 0 & 0 & 0 & 0.3 & 0 & 1.1 & 0.1 & 0 & 0 & 0 \\
\hline Spirillina & 10.1 & 15.4 & 0 & 6.6 & 0 & 0 & 9.9 & 7.9 & 23.4 & 2.8 & 15.2 & 6.9 & 5.3 & 10.2 & 5.4 & 9 & 7.7 & 19.4 & 17.1 & 9.5 & 0 & 10.4 & 9.7 & 10.2 & 14.2 & 7.3 & 23.1 & 6.7 \\
\hline Ophthalmidium & 23.3 & 0 & 0 & 0 & 0 & 0 & 4.9 & 0 & 1.1 & 0 & 0 & 0.4 & 0 & 0 & 1.3 & 2.2 & 0.3 & 0 & 0 & 0 & 0 & 0 & 0 & 0 & 0 & 0 & 0 & 0 \\
\hline Miliolidae & 0 & 0 & 0 & 0 & 0 & 0 & 0 & 0 & 0 & 0 & 0 & 0 & 0 & 8.1 & 1.3 & 5 & 0 & 0 & 0 & 0 & 0 & 0 & 0 & 0 & 0 & 0 & 0 & 0 \\
\hline Prodentalina & 1.5 & 2.9 & 0 & 1.4 & 0 & 0 & 3.3 & 11.5 & 10.7 & 7.3 & 1.7 & 6.4 & 5.3 & 11.2 & 1.3 & 3.2 & 5 & 4.8 & 0 & 0.7 & 0 & 2.2 & 1.8 & 1.1 & 0.8 & 1.2 & 0 & 6.7 \\
\hline Falsopalmula & 0.8 & 0 & 0 & 1.4 & 0 & 0 & 0.8 & 0 & 0.4 & 1.4 & 0 & 0.4 & 0 & 1.5 & 0 & 0 & 1.4 & 2.6 & 2.9 & 0 & 0 & 0.6 & 3.5 & 3.4 & 1.3 & 0.6 & 2.6 & 0 \\
\hline Nodosaria & 0.8 & 2.9 & 12.5 & 1 & 7.1 & 3.3 & 0.8 & 1.4 & 1.3 & 1.1 & 5.1 & 2.6 & 4 & 2.5 & 0 & 2.9 & 0.3 & 3.2 & 2.9 & 0.8 & 0 & 4 & 0.9 & 3.4 & 2.3 & 1.2 & 7.7 & 0 \\
\hline Pseudonodosaria & 1.5 & 1.9 & 0 & 1 & 3.6 & 0 & 1.7 & 1.1 & 1.9 & 0.8 & 1.7 & 0.9 & 0 & 2.5 & 2.7 & 1.1 & 1.3 & 0.3 & 2.9 & 0.7 & 0 & 1.3 & 0.9 & 0 & 0 & 0 & 0 & 0 \\
\hline Lenticulina & 52.7 & 66.3 & 62.5 & 66.1 & 85.7 & 83.4 & 63.9 & 40.9 & 32.2 & 66.1 & 42.4 & 60.8 & 62.7 & 52.3 & 60.8 & 63.2 & 63.2 & 52.2 & 71.4 & 75.9 & 33.3 & 69.1 & 62 & 70.5 & 62.5 & 74.4 & 43.5 & 80 \\
\hline Saracenaria & 0 & 0 & 0 & 0 & 0 & 0 & 0 & 0 & 0 & 0 & 0 & 0 & 0 & 0 & 0 & 0 & 1.3 & 0 & 0 & 0 & 0 & 0 & 0 & 0 & 0 & 0 & 0 & 6.6 \\
\hline Astacolus & 9.3 & 7.6 & 0 & 10.1 & 0 & 6.7 & 9 & 14.3 & 13.2 & 13.5 & 18.6 & 10.8 & 6.7 & 6.1 & 8.8 & 8.6 & 14.4 & 5.1 & 0 & 8.8 & 33.4 & 9.1 & 7.1 & 3.4 & 11.5 & 9.2 & 20.5 & 0 \\
\hline Citharina & 0 & 0 & 0 & 0 & 0 & 0 & 0.8 & 0.7 & 0.8 & 0.3 & 0 & 0.4 & 1.4 & 0 & 0 & 0.4 & 1.7 & 0.3 & 0 & 0 & 0 & 0.2 & 0 & 0 & 0.3 & 0 & 0 & 0 \\
\hline Planularia & 0 & 1 & 0 & 0.4 & 0 & 3.3 & 0 & 0.4 & 3 & 1.1 & 0 & 0 & 0 & 1 & 0.7 & 0.7 & 0.3 & 2.2 & 0 & 0.7 & 0 & 1 & 1.8 & 2.3 & 1.3 & 0.6 & 0 & 0 \\
\hline Vaginulina & 0 & 0 & 0 & 0 & 0 & 0 & 0 & 0 & 0 & 0 & 0 & 0 & 0 & 0 & 0 & 0 & 0.7 & 0 & 0 & 0 & 0 & 0 & 0 & 0 & 0 & 0 & 0 & 0 \\
\hline Eoguttulina & 0 & 0 & 0 & 1 & 0 & 0 & 0 & 2.5 & 1.5 & 1.1 & 0 & 3 & 5.3 & 1 & 3.4 & 1.1 & 1.7 & 4.8 & 0 & 0 & 0 & 0.5 & 0.9 & 0 & 0.5 & 0.6 & 0 & 0 \\
\hline Ceratobuliminidae & 0 & 0 & 0 & 0.4 & 0 & 0 & 0 & 0.7 & 0 & 0 & 8.5 & 0.9 & 0 & 0 & 0.7 & 0.4 & 0 & 0 & 0 & 0.7 & 33.3 & 0 & 0.9 & 0 & 0 & 0 & 0 & 0 \\
\hline Reinholdella & 0 & 1 & 25 & 3.9 & 0 & 0 & 0.8 & 3.2 & 1.1 & 0 & 1.7 & 0.9 & 0 & 0 & 1.4 & 0 & 0 & 0 & 0 & 2.2 & 0 & 0 & 3.5 & 0 & 0.9 & 2.5 & 0 & 0 \\
\hline Forams indet & 0 & 0 & 0 & 3.1 & 0 & 0 & 0 & 3.2 & 4.3 & 0.6 & 0 & 0.9 & 4 & 0 & 6.8 & 0 & 0 & 3.2 & 0 & 0 & 0 & 0.3 & 3.5 & 4.6 & 0.4 & 1.2 & 2.6 & 0 \\
\hline
\end{tabular}


minimum of 3 , always per $300 \mathrm{~g}$ of sediment sample. The number of species ranges between 27 and 3 and, concerning the relationship between the number of specimens obtained and the grams of sediment picked, a maximum of 116.2 and a minimum of 0.4 were recorded (Fig. 3B and C). From samples with less than 100 specimens, a small number of taxa was recognized. However, in these samples with a larger number of specimens, no remarkable increase in the number of identified taxa was recorded (Fig. 3A and B).

Aiming at paleoecological interpretations, quantitative analysis based on the calculation of the relative abundance and the diversity for each assemblage, was carried out. Subsequently, variations in the values obtained throughout the studied stratigraphic interval were analysed. Although the number of specimens in some assemblages is small, this analysis was carried out in all of them, as this scarcity may be related with paleoecological parameters and not with taphonomic processes.

\subsubsection{Relative abundance}

Relative abundance is expressed as a percentage, in relation to the total number of specimens obtained in each assemblage, at the suborder, genus and species rank. At the suborder rank, all the assemblages show a clear prevalence of Lagenina, with percentages that always exceed at least $65 \%$ but can attain $96 \%$. The other suborders show variable proportions, but generally lower in comparison to Lagenina (Table 1; Fig. 3D).

In most assemblages, specimens of Textulariina and Spirillinina were identified. In general, Spirillinina is more abundant than Textulariina. The analysis of the relative abundances of these suborders does not show a direct relationship between the increase in the percentages of one of them and the simultaneous decrease of the other (Fig. 3E and F).

The specimens of Robertinina are in general scarce. However, their relative abundance increases considerably in samples with a very small number of specimens. Finally, Miliolina, which shows a discontinuous record and a low percentage, is considered as a minor constituent. The only exception is M-12 (Late Toarcian), where Miliolina reaches $24 \%$.

At the generic rank, a clear prevalence of Lenticulina is observed in all the assemblages (Table 2), with percentages that vary between $32.2 \%$ and $85.7 \%$. Other genera with high percentages are Astacolus and Spirillina, both being, after Lenticulina, the most abundant in almost all the assemblages. The genera Lagenammina, Thurammina, Vaginulina, Reophax and Saracenaria can be considered as a minority.

The species of the genera Lenticulina, Astacolus and Spirillina show the highest relative abundance values, while the remaining species present low percentages that rarely exceed $10 \%$ (Fig. 2). Lenticulina münsteri is the most abundant in the majority of the assemblages, with percentages always above $10 \%$, sometimes reaching $56.7 \%$. Only locally, other species show a higher relative abundance. Hence, in M-12 the most abundant species is Ophthalmidium liasicum, which represents a $23.3 \%$ against $21.7 \%$ of Lenticulina münsteri. In M-77, Spirillina numismalis (15.2\%) prevails, followed by Lenticulina münsteri (10.2\%). In M-91, the most abundant species is Lenticulina exgaleata (13.5\%), while Lenticulina münsteri and Astacolus scalptus represent $11.8 \%$. In M-330 Spirillina orbicula (23.1\%) is the most abundant, followed by Astacolus scalptus (20.5\%), against $17.9 \%$ of Lenticulina münsteri.

\subsubsection{Diversity}

The number of taxa identified in the assemblages varies between 3 and 27 (Fig. 3B). From the Aalensis Subzone to the lower part of the Comptum Subzone the number of taxa is very irregular. From the lower part of the Comptum Subzone up to the Limitatum Subzone, the number of taxa in general increases and remains high, with small variations. The assemblages around the AalenianBajocian transition show a clear decreasing tendency.

The determined values of the Fisher's $\alpha$ index oscillate between 0 and 7.52, showing important variations throughout the studied stratigraphic interval. From the Aalensis Subzone to the lower part of the Comptum Subzone they are irregular and low, so that $\alpha<5$. From the lower part of the Comptum Subzone to the lower part of the Limitatum Subzone the values are higher, where in most cases $\alpha>5$. Finally, in the assemblages of the Aalenian-Bajocian transition the values are low again, being $\alpha<5$ (Fig. 4A).

The values of the Margalef's richness index oscillate between 1.54 and 4.30 in the studied assemblages. In

\footnotetext{
Fig. 4. (A) Values of the Fisher's $\alpha$ index and (B) values of the Margalef's richness index obtained for the studied assemblages. These values are irregular from the Aalensis Subzone to the lower part of the Comptum Subzone. Values are higher and more homogeneous from here to the lower part of the Limitatum Subzone and show a clear decreasing tendency around the Aalenian-Bajocian boundary. (C) Values of the Simpson index and (D) values of the Berger-Parker index obtained. The low values obtained for both indexes indicate no clear dominance of any species in the studied assemblages. (E) Values of the Shannon-Wiener index and (F) values of the Equitability. The values obtained for both indexes indicate high diversity, no dominance of any species and no stressful environmental conditions, throughout the studied stratigraphic interval.
} 


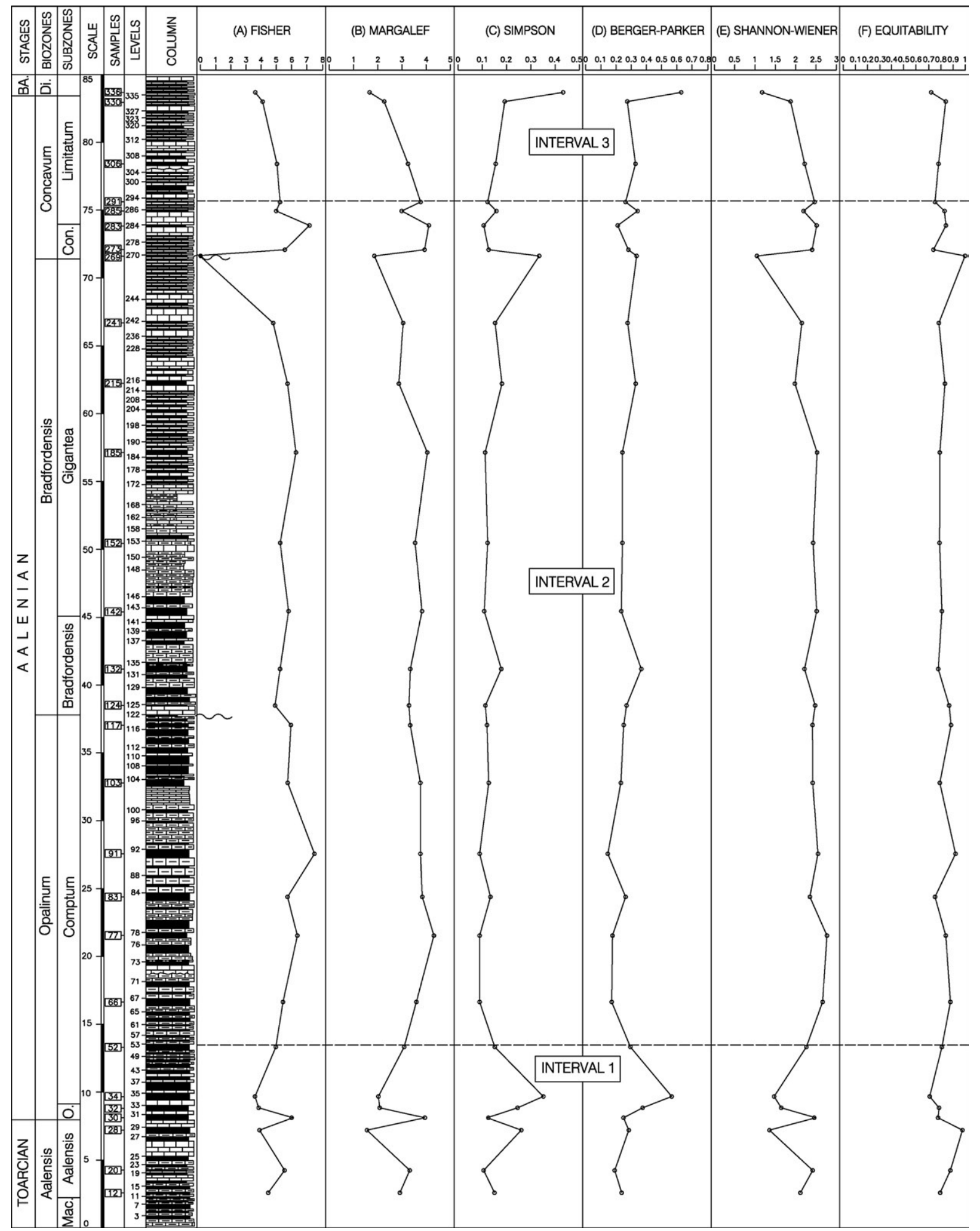


general, the obtained values are quite homogeneous (Fig. 4B), especially between the lower part of the Comptum Subzone and the lower part of the Limitatum Subzone, where they range between 3 and 4, with a few exceptions. The values calculated tend to decrease in the assemblages of the Aalenian-Bajocian transition.

In the studied assemblages the $\lambda$ values (Simpson index) vary between 0.08 and 0.44 . In most of them, they tend to be low, being $\lambda<0.3$, and this value is only exceeded in some assemblages (Fig. 4C), where the most abundant species is Lenticulina münsteri. When applying the Berger-Parker's index to the assemblages, irregular values were determined, but are in general low, ranging between 0.14 and 0.64 (Fig. 4D).

The values of the Shannon-Wiener index obtained at Murtinheira vary between 1.10 and 2.74 (Fig. 4E). From the Aalensis Subzone to the lower part of the Comptum Subzone the values are irregular. From the Comptum Subzone to the Limitatum Subzone they tend to stabilize, ranging in general between 2 and 3. The assemblages of the Aalenian-Bajocian transition show values with a decreasing tendency.

In the studied assemblages, the equitability values vary between 0.71 and 1 (Fig. 4F). Throughout the studied stratigraphic interval these values remain quite constant, without significant variations.

\section{Discussion}

The 28 foraminiferal assemblages from the Late Toarcian-Aalenian-Early Bajocian shelfal basin sediments of Murtinheira section display a total of 5411 specimens. Their distribution in the samples is irregular and, in most cases, the number of 300 specimens per $300 \mathrm{~g}$ of sediment sample was not exceeded. This number can be considered low when compared to those obtained (also per $300 \mathrm{~g}$ of sediment sample) in other correlated sections of epicontinental platforms. For instance, in the Spanish Iberian Range, Herrero and Canales (1997) obtained 10234 specimens in 23 Upper Toarcian-Lower Aalenian samples from the Fuentelsaz section, and Canales and Herrero (2000) recognized 9674 specimens in 25 samples from the Upper Toarcian-Middle Aalenian deposits from the Moyuela section. In seven Upper Toarcian-Aalenian-Lower Bajocian sections of the Basque-Cantabrian Basin, Canales (2001) described more than 6000 specimens in each section.

The preservation of the specimens is in general good (Plates I-III) and the identified taphonomic changes are negligible. Hence, the low number of specimens obtained in some of the samples may be due to adverse paleonvironmental factors affecting the communities' development.

Regarding the composition of the assemblages, the Suborder Lagenina, whose percentages always exceed $65 \%$ and ranges up to $96 \%$, dominates them all. Considering that the specimens are mainly composed of calcitic shells, a depositional depth located above CCD can be inferred.

Lenticulina is the most abundant genus in the assemblages. Its prevalence in the Aalenian-Bajocian transition assemblages from the Serra da Boa Viagem section, where 3 species of this genus and 1 of the genus Spirillina were recorded, was pointed out by Carapito and Henriques (1999). Haynes (1981) indicates that during the Jurassic, the Nodosariidae, to which Lenticulina belongs, is in general the dominant taxon in the assemblages or its only component. This author points out that the most characteristic genus during the Middle and Upper Jurassic is Lenticulina. In the same way, Murray (1989) indicates that foraminiferal assemblages of the Middle Jurassic shallow carbonate sediments are dominated by Lenticulina, Citharina and Nodosaria. In the Upper Toarcian-Aalenian-Lower Bajocian at Murtinheira, Nodosaria and Citharina are not very important constituents of the assemblages, when present. However, the most abundant genera, except for Lenticulina, are Astacolus and Spirillina.

At the specific rank, Lenticulina münsteri shows the highest relative abundance values in most of the assemblages. This prevalence over other species has been verified in other correlated European areas, such as the Cotswolds, in Great Britain (Morris, 1982), the Lusitanian Basin, in Portugal (Stam, 1985; Carapito and Henriques, 1999), the Iberian Range (Canales and Herrero, 2000) and the Basque-Cantabrian Basin (Canales, 2001), in Spain.

The Suborder Lagenina attains the maximum diversity in the middle and inner part of the platforms during the Jurassic (Johnson, 1976). Lenticulina is one of the less specialized genera and therefore could live in a variety of substrates (Haynes, 1981). During the Jurassic, it shows a broader range of habitats - including deep infaunal mode of life - than presently epifaunal and partially shallow infaunal modes of life (Tyszka, 1994a). The fact that Lenticulina is tolerant to environmental changes would explain their constant and predominant presence in all the studied assemblages. Also, the relatively high abundance of this genus, corresponding to the lenticular morphogroup, indicates that these communities lived in an oxic environment. The Jurassic foraminiferal assemblages developed in anaerobic environments are composed of species 
belonging to the flattened-planispiral, elongate-flattened and cylindrical morphogroups (Bernhard, 1986). In this sense, the microfauna described by Scheibnerová (1968) in the Opalinus Bed deposits (West Carpathians), developed in anoxic conditions, include a high percentage of agglutinated forms $(40 \%)$ and scarce smoothwalled Lenticulina, with a tendency of uncoiling the last chambers of their shells. Tyszka (1994b) indicates that samples from sediments with the lowest oxygen levels contain poor microfauna dominated by agglutinated foraminifera. The calcareous ones show a low generic diversity, with smooth-walled Lenticulina and a very low number of ornamented genera.

Other important components in the Murtinheira assemblages are Spirillinina and Textulariina, being the representatives of the first more abundant than those of the second. Murray (1989) indicates that the presence of Spirillina would indicate normal marine conditions, relatively shallow and well-oxygenated, and that the assemblages dominated by small agglutinated genera (i.e. Ammobaculites), would indicate brackish water and, probably, a certain oxygen deficit. Assemblages, in whom large agglutinated forms prevail, would be characteristic of deep areas. Tyszka (2001), after a detailed bibliographic revision, indicates that Spirillina can occurs in a wide variety of paleoenvironments, at nearly all depths, but this genus usually dominates assemblages from inner to middle neritic zones. Bouhamdi et al. (2001) show that the prevalence of the Spirillinina representatives over those of Textulariina, as well as the presence of agglutinated calcareous shells with elongated morphologies, would be indicative of assemblages developed in a platform environment. At Murtinheira, the percentages of Spirillina are important, but not dominant, in comparison with those of the other genera. In the Spanish Basque-Cantabrian Basin, the increase of the Spirillina percentage in the Aalenian assemblages was related to the transgressive part of the sedimentary cycles and hence, with the deeper parts of the platform (Canales, 2001).

The representatives of Miliolina and Robertinina can be considered, in most cases, minor components of the studied assemblages. Murray (1989) points out that the presence of Ophthalmidium indicates normal, relatively shallow and well-oxygenated marine conditions. Regarding Robertinina, he indicates that, in general, they are characteristic of normal marine conditions, except for those assemblages clearly dominated by the genus Reinholdella. This genus is a minor component in the Murtinheira section.

From a biostratigraphical point of view, many species of benthic Jurassic foraminifera show wide distribution ranges, when compared with other groups such as ammonites, which base the zonal scales for marine sediments of this System. Hence, the zonal scales based on foraminifera, proposed in different basins, show a lower stratigraphic resolution than the ammonite zones. Specifically, for the Aalenian-Bajocian interval, studies on the biostratigraphical potential of foraminifera are scarce and, according to Morris and Coleman (1989), more detailed studies on this subject should be carried out.

Most of the existing zonal scales for the studied stratigraphic interval propose the Lenticulina d'orbignyi Biozone as characteristic of the Late Toarcian and Aalenian (Wernli and Septfontaine, 1971; Gradstein, 1977, 1978; Exton and Gradstein, 1984; Copestake and Johnson, 1984; Boutakiout, 1990; Tyszka, 1999). Bartenstein and Brand (1937) established the Cristellaria (Lenticulina) d'orbignyi Biozone to characterize the Late Toarcian. Canales (2001) proposed the Dorbignyi Biozone for the Late Toarcian (Aalensis Biozone)-Middle Aalenian (Murchisonae Biozone) interval. Astacolus dorbignyi shows a virtually continuous record at Murtinheira, ranging from the Aalensis Subzone to the upper part of the Concavum Subzone. In the lower part of the studied stratigraphic interval, this species is a characteristic component of the assemblages but the record becomes discontinuous from the base of the Bradfordensis Biozone upwards.

Barbieri (1964) and Boutakiout (1990) characterize the Aalenian-Bajocian boundary based on the FO of Lenticulina quenstedti. Tyszka (1999) defines the Lenticulina quenstedti Biozone in the Bajocian (from the upper part of the Sauzei Biozone). Canales (2001) established the Quenstedti Biozone for the interval between the lower part of the Bradfordensis Subzone and the Laeviuscula Biozone (Lower Bajocian). At Murtinheira, the FO of this species was recorded at the top of the Gigantea Subzone, later than at the BasqueCantabrian Basin (Canales, 2001), and it is an important component of the assemblages in the upper part of the studied stratigraphic interval. Assemblages of the Bradfordensis Subzone in the Murtinheira section are characterized by the record of some typical Middle Jurassic species, such as Lenticulina constricta, Ammobaculites coprolithiformis, Vaginulina cf. herrerae and Prodentalina cf. mucronata. As it has already been pointed out, the establishment of a zonal scale based on foraminifera for the Lusitanian Basin demands more data from other correlated sections.

Concerning the data of the different indexes, and specifically regarding Fisher's $\alpha$ index, Murray (1991) indicates that living assemblages of benthic foraminifera 
have low $\alpha$ values in unstable, variable, marginal marine biotopes, and higher $\alpha$ values in stable, less variable, normal marine environments. At Murtinheira, from the Aalensis Subzone to the lower part of the Comptum Subzone, significant variable values were obtained. Outstanding variations were also detected in the ammonite assemblages from the middle part of the Aalensis Subzone to the upper part of the Opalinum Subzone. These variations consist on the abundance of the north-European genera Pleydellia and Leioceras alternating with the Mediterranean genera VacekiaAsthenoceras. These data may reflect extreme environmental changes that could have hindered the normal development of some foraminiferal assemblages, as well as of other groups, such as brachiopods (Andrade, 2004). From the lower part of the Comptum Subzone to the lower part of the Limitatum Subzone, the environmental conditions may have been, in general, more suitable for the development of higher diverse foraminiferal assemblages, under normal marine conditions. An exception is M-269 $(\alpha=0)$ which is associated to a sedimentary discontinuity (Henriques, 1992) (Figs. 2 and 4). In this level, the environmental conditions may have abruptly changed, seriously hindering the normal foraminiferal assemblage development and affecting other groups, like the ammonites. Environmental conditions probably also changed around the Aalenian-Bajocian transition, with a tendency to hinder the normal development of foraminiferal assemblages, since they are composed of a smaller number of specimens and taxa. At Murtinheira, this diversity decrease is not reflected in the nektonic and planktonic organisms, such as ammonoids and calcareous nannoplankton (Henriques et al., 1994). However, environmental changes seem to have affected benthic organisms such as foraminifers and brachiopods (Andrade, 2004).

Regarding Margalef's richness index, from the Aalensis Subzone to the lower part of the Comptum Subzone, the values are also irregular. Such differences may reflect unstable environmental conditions. From the lower part of the Comptum Subzone to the lower part of the Limitatum Subzone, the values increase and tend to be more homogeneous. This may indicate a higher stability in the environmental conditions, allowing the development of diverse foraminiferal assemblages. From the Limitatum Subzone to the Discites Biozone this index shows a downward tendency supporting, once again, that the environmental conditions are not the most suitable for the normal development of foraminiferal assemblages.

The Simpson index presents low values, which indicates that there is no clear dominance of any species.
In samples with relatively high values, the most abundant species is Lenticulina münsteri. The BergerParker index values reinforce the prevalence of Lenticulina münsteri.

The Shannon-Wiener index values are relatively high and, as the other indexes, they allow the recognition of the same intervals. From the Aalensis Subzone to the lower part of the Comptum Subzone the values are irregular, due to the presence of assemblages displaying very different diversity patterns. From the lower part of the Comptum Subzone to the lower part of the Limitatum Subzone, the values tend to increase and afterwards to be more constant, reflecting more stable environmental conditions. Such conditions allowed the development of diverse foraminiferal assemblages. From the lower part of the Limitatum Subzone to the Discites Biozone, the values show a clear downward tendency, displaying increasingly less diverse assemblages. Beerbower and Jordan (1969) consider that the diversity is low when $H^{\prime}<0.6$, moderate when $0.6<H^{\prime}<1$ and high when $H^{\prime}>1$. Therefore, the values of $H^{\prime}$ determined in the Murtinheira assemblages indicate high diversity.

Regarding equitability, the low values indicate conditions of high environmental stress (Haynes, 1981). Considering that calculated equitability values are high and relatively constant, no dominance of any species is detected and stressful environmental conditions do not seem to have occurred at any time.

The values of all the indexes, throughout the studied stratigraphic interval, enable the differentiation of three intervals (Fig. 4). The first one ranges from the Aalensis Subzone (Upper Toarcian) to the lower part of the Comptum Subzone (Lower Aalenian). The indexes show irregular values, displaying a rhythmic pattern. The second interval ranges from the lower part of the Comptum Subzone to the lower part of the Limitatum Subzone (Upper Aalenian). Here, the indexes values are more stable and homogeneous, indicating that no major environmental changes can be inferred. It is important to highlight that a major stratigraphic discontinuity, representing a hiatus affecting the Haugi and Murchisonae Subzones (Fig. 2), were previously recognized in the whole basin (Henriques, 1992). However, the foraminiferal assemblages and the indexes do not reflect environmental changes throughout this discontinuity. A strong concordance in their compositions, below and above the sedimentary break, is observed (Figs. 2 and 4). The last interval corresponds to the Aalenian-Bajocian transition, where the indexes values show a clear downward tendency. These values can reflect relatively unfavourable environmental conditions, which 
probably hindered the development of the foraminiferal communities.

Herrero and Canales (1997) applied the Margalef's richness, Simpson and Shannon-Wiener indexes, as well as the Equitability, to assemblages from the Lower-Middle Jurassic boundary in the Fuentelsaz Section (Iberian Range). Indexes of the Aalensis Subzone assemblages display low values of richness and diversity but they are higher and more homogeneous in the Buckmani, Opalinum and Comptum Subzones assemblages. However, the values of these indexes, from the Upper ToarcianAalenian-Lower Bajocian of the Basque-Cantabrian Basin, are more homogeneous (Canales, 2001).

Within the 44 taxa identified at Murtinheira, throughout the studied stratigraphic interval, 29 FOs and 39 LOs are recognized. This means that during this time interval, $88 \%$ of the taxa disappear. These FOs and LOs represent a gradual replacement of typical Early Jurassic species by others more characteristic of the Middle Jurassic. Most of the FOs took place throughout the Upper Toarcian and Lower Aalenian, but from the Comptum Subzone the FOs are scarcer, while the number of LOs increases. This is especially important in the Concavum Biozone, Limitatum Subzone, where a high number of LOs is identified.

The decreasing trend in the number of foraminiferal taxa near the Aalenian-Bajocian boundary is not exclusive of Murtinheira. At Serra da Boa Viagem (Lusitanian Basin), Carapito and Henriques (1999) identify a total of 44 foraminiferal species: 20 are from the Aalenian and the Bajocian, 18 are exclusive of the Aalenian and 6 have their FO in the Discites Biozone. Therefore, a general decreasing tendency in the number of species along the Aalenian-Bajocian transition is also evidenced. This same tendency has been observed in the foraminiferal assemblages studied in the Upper Aalenian deposits from different sections of the Spanish BasqueCantabrian Basin (Canales, 2001) and in the Iberian Range (Canales and Herrero, 2000).

Morris (1982) and Morris and Coleman (1989) point out that, in Great Britain, the Lower Aalenian foraminiferal assemblages are very similar to those of the Upper Toarcian. No major faunal renewal is observed at the Lower-Middle Jurassic boundary. However, they recognized a major turnover in the interval between the upper part of the Concavum Biozone and the lower part of the Discites Biozone. Foraminiferal assemblages' stability at the Toarcian-Aalenian boundary was also observed in the Fuentelsaz Section (GSSP for the Aalenian, located in the Iberian Range, Spain; Goy et al., 1994, 1996; Herrero and Canales, 1997; Cresta et al., 2001). Ruban and Tyszka (2005) recognize an important bioevent in the Aalenian foraminiferal assemblages from NW Caucasus. The assemblages show a high diversity in the first half of the Aalenian, inherited from the Toarcian. In the second half, a drastic fall in the diversity, which could be related to a regional cooling in water masses, took place. These faunas subsequently recover throughout the Bajocian.

The replacement of typical Early Jurassic foraminiferal species by Middle Jurassic ones, at the AalenianBajocian transition (Canales, 2001), has been detected in other groups besides foraminifera. Among the calcareous nannoplankton, a renewal in the assemblages has been identified in samples from the Middle Aalenian, both in the Lusitanian and in the BasqueCantabrian Basins (Perilli et al., 2002a, 2002b). A disappearance of brachiopod species in levels previous to the Aalenian-Bajocian boundary occurs at Murtinheira. A faunal recovery took place, with the appearance of typical Middle Jurassic species in the Discites Biozone (Andrade, 2004). O'Dogherty et al. (2006) pointed out an important bioevent in the history of the Mesozoic ammonites in the Upper Aalenian-Lower Bajocian of the Betic Cordillera. This bioevent is consistent with the main Jurassic faunal replacement.

Bartolini et al. (1999) studied the Middle and Upper Jurassic radiolaria in the Terminilletto section (Central Italy) and compared the obtained results with the $\delta^{13} \mathrm{C}$ curve. These authors recognize a main negative $\delta^{13} \mathrm{C}$ excursion at the Aalenian-Bajocian boundary. The radiolarian assemblages show a slight diversification trend from the base of the Bajocian, which coincides with the increase in $\delta^{13} \mathrm{C}$ values. Jenkyns et al. (2002) document low $\delta^{13} \mathrm{C}$ values measured on the Upper Aalenian (Limitatum Subzone) belemnites from Murtinheira that tend to increase in the Lower Bajocian. Concerning continental contexts, Hesselbo et al. (2003) carried out a carbon-isotope analysis of Middle Jurassic fossil wood from NE England. This analysis shows the existence of a significant excursion towards light values of $\delta^{13} \mathrm{C}$ throughout the Aalenian-Bajocian boundary. They relate this tendency to those detected in the marine environments and indicate that the isotopic signal observed represents a global phenomenon. O'Dogherty et al. (2006), in the Betic Cordillera, recognized a negative excursion in $\delta^{13} \mathrm{C}$ values just below the Aalenian-Bajocian boundary, which took place in the Limitatum Subzone in most of the studied sections. This excursion coincides with the disappearance of typical Early Jurassic ammonites, while the recovery in $\delta^{13} \mathrm{C}$ values in the Lower Bajocian coincides with the renewal of the dominant Middle and Late Jurassic forms.

The available data seem to support more and more clearly the idea, that in the Aalenian-Bajocian transition, 
a significant global carbon-cycle perturbation took place. This perturbation seems to have affected both continental and marine organisms, namely benthic and nektic invertebrates and microorganisms. Consequently, the diversity decrease in foraminiferal assemblages from the Limitatum Subzone in the Murtinheira section is probably related to this carbon-cycle perturbation.

\section{Conclusions}

The foraminiferal assemblages of the Upper ToarcianAalenian-Lower Bajocian at Murtinheira are made up, in general, of a relatively small number of specimens, compared with other correlated sections. As no evidence of significant taphonomic changes was found, the scarcity of specimens in the samples can be related to one or several paleoecological factors, which probably controlled the development of foraminiferal communities.

Specimens of the Suborder Lagenina dominate all the studied assemblages. As in other European boreal basins, Lenticulina münsteri is, in general, the most abundant species.

From a biostratigraphical point of view, some of the identified taxa show wide distribution ranges, which together with their high abundances, confer a homogeneous feature to the assemblages. However, the main foraminifera-based zones (Dorbignyi Biozone and Quenstedti Biozone), established by different authors for the studied stratigraphic interval, are recognizable at Murtinheira. Throughout this interval, a gradual replacement of typical Early Jurassic taxa by species characteristic of the Middle Jurassic can be recognized.

The paleoecological analysis carried out shows that the studied foraminiferal assemblages were developed in a well-oxygenated and normal salinity shelfal basin, and always located at depths above the CCD. The most abundant genera in these conditions are Lenticulina, Astacolus and Spirillina. The different diversity indexes indicate that environmental conditions did not remain constant throughout the studied stratigraphic interval. Initially (Upper Toarcian-Lower Aalenian), they must have been unstable and less favourable for the development of foraminiferal assemblages. During the Lower Aalenian (lower part of the Comptum Subzone)Upper Aalenian (lower part of the Limitatum Subzone) interval, environmental conditions seem to have been more stable and suitable for normal development of the assemblages. Throughout the Aalenian-Bajocian transition these conditions must have changed, providing the development of progressively less diverse foraminiferal assemblages.
Throughout the studied stratigraphic interval, the disappearance of $88 \%$ of the identified taxa has been recognized. The highest number of last occurrences is concentrated in the Upper Aalenian (Concavum Biozone, Limitatum Subzone). This could probably represent a significant faunal turnover, which requires confirmation through the study of the Bajocian foraminiferal assemblages at Murtinheira and their comparison with results described in other areas. O'Dogherty et al. (2006), who studied the Middle Jurassic ammonite distribution in the Betic Cordillera, pointed out the occurrence of an extinction event of this age. On the other hand, the possible foraminiferal faunal turnover is probably related to a synchronous perturbation of the carbon-cycle, reported by Bartolini et al. (1999), Jenkyns et al. (2002), Hesselbo et al. (2003) and O'Dogherty et al. (2006), and which can have a global range.

\section{Acknowledgements}

This study has been supported by the Projects CGL2004-02694/BTE (MEC-CSIC) and CGL200504574/BTE (MEC). The authors are grateful to R. Rocha, for his useful help in the sampling, to the Centro de Microscopía Electrónica "Luis Brú", Universidad Complutense de Madrid, for the SEM photographs, to Dr. J.J. Gómez (Universidad Complutense de Madrid), to Dr. J. Tyszka and to Dr. A. Mackensen for their critical review of the manuscript, and to Claudia Magno for the English revision of the text.

\section{Appendix A. Taxonomic appendix}

Taxonomic list of the benthic foraminiferal taxa identified in the Upper Toarcian-Aalenian-Lower Bajocian from the Murtinheira section (Lusitanian Basin, Portugal).

Determination of the specimens at the suprageneric and generic rank was carried out following the classification of Loeblich and Tappan (1988). Species are referred with its author and year of publication. The identified taxa are:

Phyllum SARCODINA Schmarda, 1871

Class RHYZOPODEA Von Siebold, 1854

Order FORAMINIFERIDA Eichwald, 1830

Suborder TEXTULARIINA Delage and Hérouard, 1896

Superfamily ASTRORHIZACEA Brady, 1881

Family Saccamminidae Brady, 1884

Subfamily Saccammininae Brady, 1884

Genus Lagenammina Rhumbler, 1911 
Lagenammina liassica (Barnard), 1959 (Plate I, Fig. 1) Subfamily Thurammininae Miklukho-Maklay, 1963 Genus Thurammina Brady, 1879

Thurammina jurensis (Franke), 1936 (Plate I, Fig. 2)

Superfamily HORMOSINACEA Haeckel, 1894

Family Hormosinidae Haeckel, 1894

Subfamily Reophacinae Cushman, 1910

Genus Reophax De Montfort, 1808

Reophax horridus (Schwager), 1865 (Plate I, Fig. 5)

Superfamily LITUOLACEA De Blainville, 1827

Family Lituolidae De Blainville, 1827

Subfamily Ammomarginulininae Podobina, 1978

Genus Ammobaculites Cushman, 1910

Ammobaculites coprolithiformis (Schwager), 1867

(Plate I, Fig. 3)

Ammobaculites fontinensis (Terquem), 1870b (Plate

I, Fig. 4)

Suborder SPIRILLININA Hohenegger and Piller, 1975

Family Spirillinidae Reuss and Fritsch, 1861

Genus Conicospirillina Cushman, 1927

Conicospirillina sp. 1 (Plate I, figs. 6a, 6b)

Genus Spirillina Ehrenberg, 1843

Spirillina numismalis Terquem and Berthelin, 1875

(Plate I, Fig. 7)

Spirillina orbicula Terquem and Berthelin, 1875

(Plate I, Fig. 8)

Suborder MILIOLINA Delage and Hérouard, 1896

Superfamily CORNUSPIRACEA Schultze, 1854

Family Ophthalmidiidae Wiesner, 1920

Genus Ophthalmidium Kübler and Zwingli, 1870

Ophthalmidium liasicum (Kübler and Zwingli), 1866

(Plate I, Fig. 9)

Family Miliolidae Ehrenberg, 1839

Miliolidae spp. (Plate I, Fig. 10)

Suborder LAGENINA Delage and Hérouard, 1896

Superfamily ROBULOIDACEA Reiss, 1963

Family Ichthyolariidae Loeblich and Tappan, 1986

Genus Prodentalina Norling, 1968

Prodentalina cf. mucronata (Neugeboren), 1856 (not illustrated)

Prodentalina pseudocommunis (Franke), 1936

(Plate I, Fig. 11)

Prodentalina subsiliqua (Franke), 1936 (Plate I, Fig. 12)

Prodentalina sp. 1 (Plate I, Fig. 13)

Family Robuloididae Reiss, 1963

Genus Falsopalmula Bartenstein, 1948

Falsopalmula jurensis (Franke), 1936 (Plate I, Fig. 14)

Superfamily NODOSARIACEA Ehrenberg, 1838

Family Nodosariidae Ehrenberg, 1838

Subfamily Nodosariinae Ehrenberg, 1838

Genus Nodosaria Lamarck, 1812

Nodosaria fontinensis Terquem, 1870b (Plate I, Fig. 15)
Nodosaria liassica Barnard, 1950 (Plate II, Fig. 1)

Nodosaria opalini Bartenstein, 1937 (Plate II, figs. 2a2b)

Nodosaria pseudoregularis Canales, 2001 (Plate II, Fig. 3)

Nodosaria pulchra (Franke), 1936 (Plate II, Fig. 4)

Genus Pseudonodosaria Boomgaart, 1949

Pseudonodosaria vulgata (Bornemann), 1854

(Plate II, figs. 5-6)

Family Vaginulinidae Reuss, 1860

Subfamily Lenticulininae Chapman, Parr and Collins, 1934

Genus Lenticulina Lamarck, 1804

Lenticulina bochardi (Terquem), 1863 (Plate II, Fig. 7)

Lenticulina constricta (Kaptarenko-Chernousova) sensu Jendryka-Fuglewicz, 1975 (Plate II, Fig. 8)

Lenticulina exgaleata Dieni, 1985 (Plate II, Fig. 9)

Lenticulina helios (Terquem), 1870a (Plate II, Fig. 10)

Lenticulina münsteri (Roemer), 1839 (fide Ellis and

Messina, 1940-1990) (Plate II, Fig. 11)

Lenticulina polygonata (Franke), 1936 (Plate II, Fig. 12)

Lenticulina quenstedti (Gümbel), 1862 (Plate II, Fig. 13)

Lenticulina toarcense Payard, 1947 (Plate III, Fig. 1)

Genus Saracenaria Defrance, 1824

Saracenaria sp. 1 (Plate III, Fig. 2)

Subfamily Marginulininae Wedekind, 1937

Genus Astacolus De Montfort, 1808

Astacolus dorbignyi (Roemer), 1839 (fide Ellis and

Messina, 1940-1990) (Plate III, Fig. 3)

Astacolus scalptus (Franke), 1936 (Plate III, Fig. 4)

Astacolus varians (Bornemann), 1854 (Plate III,

Fig. 5)

Astacolus sp. 1 (Plate III, Fig. 6)

Subfamily Vaginulininae Reuss, 1860

Genus Citharina d'Orbigny, 1839

Citharina clathrata (Terquem), 1863 (Plate III, Fig. 7)

Citharina colliezi (Terquem), 1866 (Plate III, Fig. 8)

Genus Planularia Defrance, 1826

Planularia aff. beierana (Gümbel), 1862 (Plate III, Fig. 9)

Planularia cordiformis (Terquem), 1863 (Plate III, Fig.10)

Planularia cf. eugenii (Terquem), 1864 (not illustrated) Planularia protracta (Bornemann), 1854 (Plate III,

Fig. 11)

Genus Vaginulina d'Orbigny, 1826

Vaginulina cf. herrerae Canales, 2001 (Plate III, Fig. 12)

Family Polymorphinidae d'Orbigny, 1839

Subfamily Polymorphininae d'Orbigny, 1839

Genus Eoguttulina Cushman and Ozawa, 1930

Eoguttulina liassica (Strickland), 1846 (Plate III,

Fig. 13) 
Suborder ROBERTININA Loeblich and Tappan, 1984 Superfamily CERATOBULIMINACEA Cushman, 1927

Family Ceratobuliminidae Cushman, 1927

Ceratobuliminidae (Plate III, Figs. 14-15)

Subfamily Reinholdellinae Seiglie and Bermúdez, 1965

Genus Reinholdella Brotzen, 1948

Reinholdella dreheri (Bartenstein), 1937 (not illustrated)

\section{Appendix B. Supplementary data}

Supplementary data associated with this article can be found, in the online version, at doi:10.1016/j. marmicro.2008.01.003.

\section{References}

Andrade, J.B., 2004. Los braquiópodos del tránsito Jurásico InferiorJurásico Medio de la Cuenca Lusitánica (Portugal). Ph.D. Thesis, Complutense de Madrid Univ., Spain.

Azerêdo, A.C. 1993. Jurássico Médio do Maciço Calcário Estremenho (Bacia Lusitânica): análise de fácies, micropaleontologia, paleogeografía. Ph.D. Thesis, Lisboa Univ., Portugal.

Azerêdo, A.C., 1995. Foraminíferos bentónicos do Dogger da Bacia Lusitânica: valor estratigráfico e controlo ambiental. Mem. - Mus. Lab. Mineral. Geol. Fac. CieÃnc. Univ. Porto 4, 29-32.

Azerêdo, A.C., 1999. Études micropaléontologiques dans les séries carbonatées du Jurassique moyen du Bassin Lusitanien (Portugal). Comun. Inst. Geol. Min. 86, 59-84.

Azerêdo, A.C., Duarte, L.V., Henriques, M.H., Manuppella, G., 2003. Da dinâmica continental no Triásico aos mares do Jurássico Inferior e Médio. Cad. Geol. Portugal. Inst. Geol. Min. 1, 6-43.

Barbieri, F., 1964. Micropaleontologia del Lias e Dogger del pozzo Ragusa 1 (Sicilia). Riv. ital. Paleontol. Stratigr. 70, 709-830.

Bartenstein, H., Brand, E., 1937. Mikro-paläontologische Untersuchungen zur Stratigraphie des nordwest-deutschen Lias und Doggers. Abh. Senckenb. Naturforsch. Ges. 439, 1-224.

Bartolini, A., Baumgartner, P.O., Guex, J., 1999. Middle and Late Jurassic radiolarian palaeoecology versus carbon-isotope stratigraphy. Palaeogeogr. Palaeoclimatol. Palaeoecol. 145, 43-60.

Beerbower, J.R., Jordan, D., 1969. Application of information theory to paleontologic problems: Taxonomic diversity. J. Paleontol. 43, 1184-1198.

Bernhard, J.M., 1986. Characteristic assemblages and morphologies of benthic foraminifera from anoxic, organic-rich deposits: jurassic through Holocene. J. Foraminiferal Res. 16, 207-215.

Bouhamdi, A., Gaillard, C., Ruget, C., 2001. Spirillines versus agglutinants: impact du flux organique et intérêt paléoenvironnemental (Oxfordien moyen du Sud-Est de la France). Geobios 34, 267-277.

Boutakiout, M., 1990. Les foraminifères du Jurassique des Rides sudrifaines et des régions voisines (Maroc). Doc. Lab. Géol. Lyon 112, 1-247.

Brilha, J., Andrade, C., Azerêdo, A.C., Barriga, F.J.A.S., Cachão, M., Couto, H., Cunha, P.P., Crispim, J.A., Dantas, P., Duarte, L.V., Freitas, M.C., Granja, M.H., Henriques, M.H., Henriques, P., Lopes, L., Madeira, J., Matos, J.M.X., Noronha, F., Pais, J., Piçarra,
J., Ramalho, M.M., Relvas, J.M.R.S., Ribeiro, A., Santos, A., Santos, V., Terrinha, P., 2005. Definition of the Portuguese frameworks with international relevance as an input for the European geological heritage characterization. Episodes 8, 177-186.

Canales, M.L., 2001. Los foraminíferos del Aaleniense (Jurásico Medio) en la Cuenca Vasco-Cantábrica (N de España). Rev. Esp. Micropaleontol. 33, 253-438.

Canales, M.L., Herrero, C., 2000. Asociaciones de foraminíferos del Toarciense superior y Aaleniense en la sección de Moyuela (Zaragoza, España). Rev. Esp. Micropaleontol. 32, 301-317.

Canales, M.L., Henriques, M.H., Ureta, S., 2000. Análisis de las asociaciones de foraminíferos del Aaleniense en los márgenes oriental y noroccidental de la Placa Ibérica: implicaciones biogeográficas y bioestratigráficas. Proc. I Congr. Iber. Paleontol./XVI Jornadas Soc. Esp. Paleontol., Évora, Portugal, pp. 8-9.

Carapito, M.C., Henriques, M.H., 1999. Foraminiferal biostratigraphy and paleoecology of the Aalenian-Bajocian boundary at the Cabo Mondego area. Proc. Europ. Palaeontol Assoc. Workshop, Lisboa, Portugal, pp. 35-38.

Copestake, P., Johnson, B., 1984. Lower Jurassic (HettangianToarcian) Foraminifera from the Mochras Borehole, North Wales (UK) and their application to a worldwide biozonation. In: Oertli, H.J. (Ed.), 2nd Int. Symp. on Benthic Foraminifera (Pau and Bordeaux, 1983). Elf Aquitaine, Esso REP and Total CFP, pp. 183-184.

Cresta, S., Goy, A., Ureta, S., Arias, C., Barrón, E., Bernad, J., Canales, M.L., García-Joral, F., García-Romero, E., Gialanella, P.R., Gómez, J.J., González, J.A., Herrero, C., Martínez, G., Osete, M.L., Perilli, N., Villalaín, J.J., 2001. The global boundary stratotype section and point (GSSP) of the Toarcian-Aalenian Boundary (Lower-Middle Jurassic). Episodes 24, 166-175.

Duarte, L.V., 1997. Facies analysis and sequential evolution of the Toarcian-Lower Aalenian series in the Lusitanian Basin (Portugal). Comun. Inst. Geol. Min. 84, A60-A63.

Exton, J., 1979. Pliensbachian and Toarcian microfauna of Zambujal (Portugal): systematic paleontology. Geol. Pap. -Carleton Univ., Dep. Geol. 79, 1-100.

Exton, J., Gradstein, F.M., 1984. Early Jurassic stratigraphy and micropaleontology of the Grand Banks and Portugal. In: Westermann, G.E.G. (Ed.), Jurassic-Cretaceous Biochronology and Paleogeography of North America. Spec. Pap. -Geol. Assoc. Can., vol. 27, pp. 13-30.

Goy, A., Ureta, S., Arias, C., Canales, M.L., García Joral, F., Herrero, C., Martínez, G., Perilli, N., 1994. The Fuentelsaz section (Iberian Range, Spain), a possible stratotype for the base of the Aalenian Stage. Miscellanea Ser. Geol. Nazionale 5, 1-31.

Goy, A., Ureta, S., Arias, C., Canales, M.L., García Joral, F., Herrero, C., Martínez, G., Perilli, N., 1996. Die Toarcium/Aalenium Grenze im Profil Fuentelsaz (Iberische Ketten, Spanien). Inf. -Geol. Landesamt Baden-Württ. 8, 43-52.

Gradstein, F.M., 1977. Biostratigraphy and biogeography of Jurassic Grand Banks foraminifera. In: Schafer, G.H.T., Bernard, R.P. (Eds.), 1st Int. Symp. on Benthonic Foraminifera of Continental Margins. Part B: Paleoecology and Biostratigraphy (Halifax, 1975). Marit. sediments, Spec. Publ., vol 1, pp. 557-583.

Gradstein, F.M., 1978. Jurassic grand banks foraminifera. J. Foraminiferal. Res. 8, 97-109.

Hammer, Ø., Harper, D.A.T., 2006. Paleontological Data Analysis Blackwell Publishing, Oxford.

Hammer, Ø., Harper, D.A.T., Ryan, P.D., 2001. PAST: paleontologycal statistics software package for education and data analysis Palaeontol. Electronica 4, 9 pp. 
Haq, B.U., Hardenbol, J., Vail, P.R., 1988. Mesozoic and Cenozoic chronostratigraphy and cycles of sea-level change. In: Wilgus, C.K., et al. (Ed.), Sea-level Changes: An Integrated Approach. SEMP Spec. Publ., vol. 42, pp. 71-108.

Haynes, J.R., 1981. Foraminifera. Macmillan Publishers Ltd., London.

Henriques, M.H., 1989. O limite Lias-Dogger no Baixo Mondego (Portugal). Ensaio de caracterizaçao biostratigráfica. Mem. Not., Publ. Mus. Lab. Mineral. Geol. Univ. Coimbra 107, 37-42.

Henriques, M.H., 1992. Biostratigrafia e Paleontología (Ammonoidea) do Aaleniano em Portugal (Sector Setentrional da Bacia Lusitaniana). Ph.D. Thesis, Coimbra Univ., Portugal.

Henriques, M.H., 1995. Les faunes d'ammonites de l'Aalenien portugais: composition et implications paleobiogéographiques. Geobios, Mem.Spec. 18, 229-235.

Henriques, M.H., Ramalho, M.M., 2005. Jurassic heritage of Cabo Mondego (Central Portugal). In: Henriques, M.H., Azerêdo, A.C., Duarte, L.V., Ramalho, M.M. (Eds.), Jurassic Heritage and Geoconservation in Portugal: Selected Sites, IV Int. Symp. ProGEO on the Conservation of the Geological Heritage, Field Trip Guide Book, Geosciences Centre, University of Coimbra, pp. 37-43.

Henriques, M.H., Gardin, S., Gomes, C.R., Soares, A.F., Rocha, R.B., Marques, J.F., Lapa, M.R., Montenegro, J.D., 1994. The Aalenian-Bajocian boundary at Cabo Mondego (Portugal). Miscellanea Ser. Geol. Nazionale 5, 63-67.

Henriques, M.H., Soares, A.F., Carapito, M.C., 1995. O limite Aaleniano-Bajociano. O perfil da Serra da Boa Viagem (Portugal). Mem. - Mus. Lab. Mineral. Geol. Fac. CieÃnc. Univ. Porto 4, 97-100.

Herrero, C., Canales, M.L., 1997. Diversidad en los foraminíferos del tránsito Toarciense/Aaleniense en la sección de Fuentelsaz (Cordillera Ibérica). Rev. Esp. Paleontol. 12, 233-242.

Hesselbo, S.P., Morgans-Bell, H.S., McElwain, J.C., Rees, P.M., Robinson, S.A., Ross, C.E., 2003. Carbon-cycle perturbation in the Middle Jurassic and accompanying changes in the terrestrial paleonvironment. J. Geol. 111, 259-276.

Jenkyns, H.C., Jones, C.E., Gröcke, D.R., Hesselbo, S.P., Parkinson, D.N., 2002. Chemostratigraphy of the Jurassic System: applications, limitations and implications for palaeoceanography. J. Geol. Soc. Lond. 159, 351-378.

Johnson, B., 1976. Ecological ranges of selected Toarcian and Domerian (Jurassic) foraminiferal species from Wales. In: Schafer, G.H.T., Bernard, R.P. (Eds.), 1st Int. Symp. on Benthonic Foraminifera of Continental Margins. Part B: Paleoecology and Biostratigraphy (Halifax, 1975). Marit. sediments, Spec. Publ., vol. 1, pp. 545-556.

Loeblich, A.R., Tappan, H., 1988. Foraminiferal Genera and Their Classification. Van Nostrand Reinhold Company, New York.

Magurran, A.E., 1988. Ecological Diversity and Its Measurement. Chapman and Hall, London.

Morris, P.H., 1982. Distribution and palaeoecology of Middle Jurassic Foraminifera from the Lower Inferior Oolithe of the Cotswolds. Palaeogeogr. Palaeoclimatol. Palaeoecol. 37, 319-347.

Morris, P.H., Coleman, B.E., 1989. The Aalenian to Callovian (Middle Jurassic), In: Jenkins, D.G., Murray, J.W. (Eds.), Stratigraphical Atlas of Fossil Foraminifera, second ed. Ellis Horwood Limited, Chichester, UK, pp. 189-236.

Murray, J.W., 1989. An outline of faunal changes through the Phanerozoic, In: Jenkins, D.G., Murray, J.W. (Eds.), Stratigraphical Atlas of Fossil Foraminifera, second ed. Ellis Horwood Limited, Chichester, UK, pp. 570-573.
Murray, J.W., 1991. Ecology and distribution of benthic foraminifera. In: Lee, J.J., Andreson, O.R. (Eds.), Biology of Foraminifera. Academic Press Limited, UK, pp. 221-253.

O’Dogherty, L., Sandoval, J., Bartolini, A., Bruchez, S., Bill, M., Guex, J., 2006. Carbon-isotope stratigraphy and ammonite faunal turnover for the Middle Jurassic in the Southern Iberian palaeomargin. Palaeogeogr. Palaeoclimatol. Palaeoecol. 239, 311-333.

Pavia, G., Enay, R., 1997. Definition of the Aalenian-Bajocian Stage Boundary. Episodes 20, 16-22.

Perilli, N., Henriques, M.H., Giannetti, M., 2002a. Aalenian calcareous nannofossils changes and Lotharingius/Watznaueria turnover: evidence from the Lusitanian Basin (Portugal). J. Nannoplankton Res. 24, 145.

Perilli, N., Henriques, M.H., Ureta, M.S., 2002b. Aalenian calcareous nannofossil biohorizons of some sections, from Lusitanian Basin and Basque-Cantabrian Area. Publ. Semin. Paleontol. Zaragoza 5, $162-166$.

Rocha, R.B., Henriques, M.H., Soares, A.F., Mouterde, R., Caloo, B., Ruget, C., Fernández-López, S., 1990. The Cabo Mondego Section as a possible Bajocian boundary stratotype. Mem. Descr. Carta Geol. Ital. 60, 49-60.

Ruban, D.A., Tyszka, J., 2005. Diversity dynamics and mass extinctions of the Early-Middle Jurassic foraminifera: a record from the Northwestern Caucasus. Palaeogeogr. Palaeoclimatol. Palaeoecol. 222, 329-343.

Ruget, C., 1985. Les Foraminifères (Nodosariidés) du Lias de L’Europe occidentale. Doc. Lab. Géol. Lyon 94, 1-272.

Ruget, C., Cubaynes, R., Nicollin, J.P., Roquet, A.M., 1989. Une méthode de traitement (prélèvement, lavage, tri) pour l'analyse paléoécologique appliquée aux nodosariidés du Toarcien des coupes de Penne et de Caylus (Quercy, France). Rev. Micropaléontol. 32, $45-52$.

Scheibnerová, V., 1968. On the discovery of Microfauna in the Opalinus Beds (Klippen Belt, West Carpathians). Mitt. Bayer. Staatssamml. Paläontol. hist. Geol. 8, 51-65.

Stam, B., 1985. Quantitative analysis of Middle and Late Jurassic foraminifera from Portugal and its implications for the Grand Banks of Newfoundland. Utrecht micropaleontol. bull. 34, 1-168.

Tyszka, J., 1994a. Response of Middle Jurassic benthic foraminiferal morphogroups to dysoxic/anoxic conditions in the Pieniny Klippen Basin, Polish Carpathians. Palaeogeogr. Palaeoclimatol. Palaeoecol. 110, 55-81.

Tyszka, J., 1994b. Paleoenvironmental implications from ichnological and microfaunal analyses of Bajocian Spotty Carbonates, Pieniny Klippen Belt, Polish Carpathians. Palaios 9, 175-187.

Tyszka, J., 1999. Foraminiferal biozonation of the Early and Middle Jurassic in the Pieniny Klippen Belt (Carpathians). Bull. Pol. Acad.: Earth Sci. 47, 27-46.

Tyszka, J., 2001. Microfossil assemblages as bathymetric indicators of the Toarcian/Aalenian «Fleckenmergel»-facies in the Carpathian Pieniny Klippen Belt. Geol. Carpath. 52, 147-158.

Watkinson, M.P., 1989. Triassic to Middle Jurassic sequences from the Lusitanian Basin Portugal, and their equivalents in other North Atlantic margin basins. Ph.D. Thesis, Open Univ., Great Britain.

Wernli, R., Septfontaine, M., 1971. Micropaléontologie comparée du Dogger du Jura méridional (France) et des Préalpes Médianes Plastiques romandes (Suisse). Eclogae Geol. Helv. 64, 437-458. 